\title{
Before Humpty Dumpty: the first English empire and the brittleness of
}

\author{
bureaucracy, $1259-1453^{1}$
}

\section{PETER CROOKS}

'No Caesar or Charlemagne ever presided over a dominion so peculiar', exclaimed Benjamin Disraeli in a speech of April 1878 on what he imagined to be the singular diversity of the nineteenth-century British empire. ${ }^{2}$ But what about the Plantagenets? In the later Middle Ages, the Plantagenet kings of England ruled, or claimed to rule, a consortium of insular and continental possessions that extended well outside the kingdom of England itself. At various times between the treaty of Paris in 1259 and the expulsion of the English from France (other than the Pale of Calais) in 1453, those claims to dominion stretched to Scotland in the north, Wales and Ireland in the west, Aquitaine (or, more specifically, Gascony) in the south of France, and a good deal else in between. By the standards of the 'universal empires' of antiquity or the globe-girdling empires of the modern era, the late-medieval English 'empire' was a small-scale affair. It was no less heterogeneous for its relatively modest size. Rather it was a motley aggregation of hybrid settler colonies gained by conquest, and lands (mostly within the kingdom of France) claimed by inheritance though held by the sword. The constitutional relationship of the constituent parts to the crown of England was vaguely defined. There were marked differences in law and custom between the dominions, and variations in the legal status of the king's subjects. ${ }^{3}$ Across-indeed within — the dominions, administration was geographically fragmented, and there were marked modulations in the intensity of government. ${ }^{4}$ Given all the diversity and flux, one might well query whether 'empire’ is the appropriate word at all. ${ }^{5}$ 
This essay starts from the assumption that it is the very peculiarity of the wider realm of the Plantagenet monarchs that makes it typical when considered in comparative terms as an empire. ${ }^{6}$ Among the structures that provided a degree of cohesion more than sufficient to warrant the ascription of that label was the royal bureaucracy. ${ }^{7}$ The 'transnational' nature of this bureaucracy, and its role in creating a political culture and a shared imperial 'space', are key themes in the pages that follow. A second theme, paradoxically, is the brittleness of that same bureaucracy. The overseas empire of the Plantagenets was unusual in the late Middle Ages for its capacity to mobilise resources and co-ordinate action across geographically dispersed territories. By comparison, the Catalan overseas 'empire’ of the thirteenth and fourteenth centuries has been shown to be a chimera. ${ }^{8}$ And yet, for all the sophistication of its military and bureaucratic apparatus, the administrative reach of England's medieval empire was frequently beyond its grasp. Many of the lands that came into Plantagenet possession, whether through inheritance or conquest or a combination of the two, were subsequently lost—sometimes wrested away in wars of re-conquest (as occurred in Scotland and France), sometimes lost by piecemeal nibbling at the edges (as occurred across much of Ireland). The final part of the chapter seeks to show that an explanation for this brittleness must take account of the markedly different attitudes of officialdom towards the various peoples subject to the English crown. The key question is not to what extent was the English 'official mind' willing to devolve power upon local elites in general, but rather which particular ethnic groups were deemed sufficiently responsible and civilized to exercise the offices of government, and how did the 'rule of difference' constrain the Plantagenets' exercise of power across their empire. 
I

\section{CONCEPTS IN QUESTION}

With some notable exceptions, historians of the late Middle Ages have been slow to adopt 'empire’ as a conceptual frame through which to draw together the histories of England's continental and archipelagic possessions. ${ }^{9}$ The seminal study of the 'first English empire’ by R. R. Davies was, for instance, primarily concerned with England's impact on its insular neighbours in Britain and Ireland. ${ }^{10}$ It is only recently that historians have thought to pursue the trail blazed by John Le Patourel, who sought to comprehend all the king's territorial possessions, whether located on the European mainland or in the 'British Isles', as a political system. $^{11}$

In this respect, historians of the (post-medieval) British empire long ago stole a march on medievalism when their interest in constitutional precedent and institutional origins set them on a whiggish quest for the 'foundations of a colonial system of government'. ${ }^{12}$ They found what they sought in the late Middle Ages. In 1950 Julius Goebel published an essay whose title employed a metaphor more likely to evoke, in a contemporary readership, the dystopian virtual network of cyberpunk science fiction- 'The matrix'—than the image of incubation and incipient growth that its author originally intended. ${ }^{13}$ For Goebel, the Middle Ages were a period of institutional gestation; the Plantagenets, the unwitting midwives to an infant British imperial constitution: 'When the first expeditions were outfitted for America’, he disclosed, 'the English were already old hands in the business of empire.' ${ }^{14}$ A generation later Freddie Madden reached a similar conclusion when he surveyed the Middle Ages for its 'relevance' to the post-medieval constitutional development of empire: 'Before ever [an] Elizabethan adventurer set foot in the New World there were five centuries (or more) of precedent stored away in the minds and archives of English officials. ${ }^{, 15}$ There the matter appears to have rested. When, during the mid-1990s, the Humpty Dumpty historiography of 
the British empire was pieced together again with the publication of the Oxford history of the British empire ${ }^{16}$ the 'origins of empire' were located in the late sixteenth and seventeenth centuries, with no more than a throwaway glance at medieval antecedents. ${ }^{17}$

It was the achievement of the Humpty Dumpty school to demonstrate that the farflung polity ruled by England's medieval kings could be conceptualized as an empire in terms of its institutional structure. In the lexicon of the present volume, their concern was with the interplay of ‘empire’ and 'bureaucracy'. But the argument for straightforward continuity is problematical. Placed in diachronic perspective, the medieval English empire shows off a higher degree of central superintendence and institutional coherence than Britain’s 'bureaucratically challenged' empire in colonial north America, at least until the later seventeenth century. ${ }^{18}$ Indeed, if the relational system between imperial core and overseas dominions resembles anything in the early modern era, it is the transatlantic bureaucracy of the Spanish monarchy. ${ }^{19}$ Comparisons of this kind have yet to be properly worked out. As Robin Frame recently remarked: “The "English empire” may have been a small affair compared to the "Spanish system" of the early modern period, upon which so much ink has been expended; nevertheless, the character and speed of communications_-and the whole business of networking and decision-making-deserves fuller study' ${ }^{20}$

In part, but only in part, the reluctance of medievalists to engage in comparisons of this kind may be explained by the fact that the wider realm of the Plantagenet monarchs was an 'unlabelled empire'. ${ }^{21}$ In unofficial contexts England might be vaunted or decried as an empire by analogy with the ancient world monarchies. Bishop Thomas Brinton of Rochester (d. 1389) employed the trope of imperial decline in 1375 when he compared England to the archetypal empire of antiquity: 'The kingdom of England has, in the manner of Rome, been called the kingdom of kingdoms, because it has had so many victories, has captured so many kings, and has seized so many dominions ... But I fear that because of all our sins, our 
kingdom has decayed and collapsed, and God, who used to be English, has withdrawn from us. ${ }^{22}$ This was the language of the sermon, not the official record. The king's ministers had no single collective noun to describe the wider realm. Instead, they resorted to omnibus phrases to refer to the dominions, such as the 'lordships and possessions overseas pertaining to the crown of England' or his 'lands and lordships overseas' ${ }^{23}$ Nor was the title 'emperor' part of royal style, notwithstanding the appearance in the thirteenth century of the maxim that the 'king is emperor in his own realm' (L. rex in regno suo est imperator), which served as an assertion of England's national sovereignty. ${ }^{24}$ None of these deficiencies in imperial nomenclature prevented the Plantagenets from basking in the reflected glory of empires past. Upon his return to England after his victory over the French at the battle of Agincourt in 1415, Henry V (r. 1413-22) entered the city of London in the manner of an imperial triumph wearing a gown of purple and followed by a train of his prisoners. ${ }^{25}$

Perhaps more significant as an explanation for the historical neglect of 'empire' is the fact that medievalists have, by and large, been more interested in matters of 'state' than 'empire' - specifically the origins or 'genesis' of the modern state. ${ }^{26}$ In this context, England appears as a precocious exemplar of a Europe-wide political development, providing an early case of the convergence of 'nation' and 'state'. ${ }^{27}$ Bureaucracy bulks large in this model. Indeed the word is something of a shibboleth among historians of medieval English government. ${ }^{28}$ The tone was set by the doyen of English administrative history, T. F. Tout (d. 1929). In a lecture delivered in 1915, Tout noted that the term 'civil service' originated with the English East India Company after Clive’s conquest of Bengal, but he had no doubt that the history of a professional administration within England itself was much older: 'Whether or not we have the name, we have the thing, hundreds of years earlier. ${ }^{29}$ Inspired by Tout, several generations of English administrative and institutional historians operated within the assumption that the primary object of their labours was the kingdom of England. 
Although the spectre of Max Weber rarely makes its presence felt in the work of these historians, their empirical findings fit some of the features of the weberian ideal type of 'bureaucracy'. ${ }^{30}$ By the mid-fourteenth century, the English monarchy presided over what was, for its time in the Latin West, an administrative behemoth staffed by careerist functionaries several hundred strong. The central government was based primarily at Westminster, although between 1298 and 1330 the offices of state periodically 'migrated' northwards to York, so to be closer to the king on campaign in Scotland. ${ }^{31}$ The administration was increasingly differentiated and specialized: witness the long-established division by function not only between the secretarial (the chancery), financial (the exchequer and wardrobe) and judicial departments, but further sub-divisions within the secretariat between the chancery and the offices of the privy seal and signet. ${ }^{32}$ The internal organization of departments was hierarchical, perhaps most obviously in the case of the chancery for which we have a detailed list of ordinances (1388-9). ${ }^{33}$ Below the chief office of chancellor of England were a hundred or so chancery clerks. At their head were twelve 'masters' or 'clerks of the first form', followed by a further twelve 'clerks of the second form', twenty-four cursitors, and a large pool of assistants and servants. The king's ministers and clerks took a fee in their office, but since they were normally unmarried clerics—marriage being, in theory, subject to government prohibition as late as the reign of Henry $\mathrm{V}$ - they might also receive rewards in promotion to ecclesiastical livings and benefices. ${ }^{34}$ The occupants of the higher echelons of royal service often had university degrees and, increasingly during the fifteenth century, legal education. ${ }^{35}$ These mandarins offered English kings an impressive portfolio of services in furtherance of imperialist enterprises: a flair for legal casuistry was useful in diplomacy and treaty negotiation, while jingoistic propaganda sold the war-effort to the domestic audience, not least in parliament so as to prise open the purse-strings of the English commons. ${ }^{36}$ The lesser clerks received what would now be called in-house vocational 
training, and shared an esprit de corps gleaned from, among other things, their common livings in the Inns of Chancery. ${ }^{37}$ Finally, this was routine administration based on 'the files'. In any one year, the administration engrossed, sealed and issued as many as fifty-thousand writs. $^{38}$ The chancery registered much of the outgoing correspondence, which was normally written in Latin, on parchment rolls ostensibly for its internal reference, though the enrolment of hundreds of ephemeral documents served no practical purpose other than to satisfy the expectations of bureaucratic routine. ${ }^{39}$ Before the turn of the fourteenth century the English chancery was producing ten major series of enrolments, and many more were added in time. ${ }^{40}$ The sheer drudgery of it all was recorded in the verse of the poet-bureaucrat Thomas Hoccleve (d. 1426), whose day-job saw him toiling in the office of the privy seal where he stared in silence ‘upon the sheep’s skin’ (membranes of parchment) keeping his songs and words within. ${ }^{41}$

Jean-Philippe Genet has identified the 'critical phase' in the formation of this machinery of state as the decades between $c .1280$ and $c .1360 .^{42}$ The explanation for its development is seductively simple. The waging of near-continuous war, and the need to fund armies through taxation, set in motion a mutually-reinforcing process of war-making and governmental growth that brought forth a 'fiscal-military state' ${ }^{43}$ The aspect of the analysis that has been comparatively neglected is that the same formative decades in the construction of the state were also a critical phase in the extension of England's bureaucratic reach outside its original borders. A few intrepid English historians—notably H. G. Richardson (d. 1974) and G. O. Sayles (d. 1994) — followed the trail of parchment to compile studies of England's dependent or devolved administrations; but the general tendency has been for work of this kind to carried on 'locally', resulting in a historiography compartmentalised along 'national' lines rather than brought into satisfactory correlation. ${ }^{44}$ To the analysis of war-making and state formation we need, then, to add a third dimension: empire-building. 
The emergence of England as the core of an overseas empire was a development of the mid- to late-thirteenth century. After the loss of Normandy in 1204 and the French conquest of Poitou in 1224 (described by John Gillingham, above), the two principal overseas possessions remaining to the Plantagenets were Ireland and Aquitaine.

[Fig. 11.1. England and the Plantagenet dominions in the later Middle Ages]

Under the terms of the treaty of Paris (1259), Henry III (r. 1216-72) renounced his claims to Normandy, Anjou, Touraine, Maine and Poitou to Louis IX of France (r. 1226-70). ${ }^{45}$ This left only the Channel Islands in English possession as a relic of duchy of Normandy. ${ }^{46}$ The disputed status of Aquitaine was a major point of contention between England and France. Was the duchy, as Henry III had conceded in the treaty of Paris, a fief held of the king of France in liege homage? Or was it, as the Gascons believed and Edward I sought to argue in 1298, an hereditary estate (an 'allod') held by the Plantagenets in sovereignty with no superior save God? ${ }^{47}$ The irreconcilability of these opinions contributed to the outbreak in 1337 of the conflict between England and France that was fought, in fits and starts, for well over a hundred years. ${ }^{48}$

[Fig. 11.2. The Plantagenet kings of England to 1460]

The final quarter of the thirteenth century was an era of 'new imperialism' within Britain, characterized by annexations and the expropriation of native rulers in the south and north of Wales between 1277 and 1283, and in Scotland (albeit with markedly less success) after 1296. ${ }^{49}$ Edward I (r. 1272-1307) took direct control of south Wales piecemeal after 1277, a development occasioned by war of 1277-8 against Llywelyn ap Gruffudd, the native 
prince of Wales. In 1279 Edward I acquired the castles of Carmarthen and Cardigan, which became the administrative centres of two new shires, each castle being fitted out with its own exchequer overseen from 1299 by the chief financial officer: the chamberlain of south Wales. ${ }^{50}$ The death of Llywelyn ap Gruffudd late in 1282 while in rebellion against Edward I was followed in 1283 by the capture and grisly execution for treason of Llywelyn's brother, Dafydd. With Dafydd's death the line of Welsh princes supplied by the native dynasty of Gwynedd was all-but extinguished. ${ }^{51}$ Edward I annexed Gwynedd Uwch Conwy ('beyond the Conwy') to the crown, creating the principality of North Wales comprising three shires of Anglesey, Caernarfon and Merioneth, whose English sheriffs were answerable to the chamberlain of the newly-established exchequer at Caernarfon; a fourth county of Flint was administered from Chester. ${ }^{52}$ The Statute of Wales (1284) introduced much of the apparatus of English government and criminal law; Welsh law was tolerated in civil pleas. ${ }^{53}$

Between 1296 and 1328, the English sought to convert a long-standing claim to superior lordship over the kingdom of the Scots into direct rule. ${ }^{54}$ Following the massacre of its townspeople in 1296, the town of Berwick-on-Tweed was colonized with English merchants and Edward I established a 'Berwick exchequer' which was to follow the procedures of the royal exchequer at Westminster. ${ }^{55}$ Berwick and its hinterland served as the headquarters of an embattled colonial administration from which the English sought to project their power into Scotland until the town was lost to the Scots in $1318 .^{56}$ When the Anglo-Scottish conflict resumed in 1332-3, Edward III achieved, albeit temporarily, a more radical dismemberment of Scotland when the claimant to the Scottish throne Edward Balliol (d. 1364) ceded six sheriffdoms in lowland Scotland: these lands were annexed to the kingdom of England and described as 'the king's land beyond the [river] Tweed'; the remainder of Scotland was to be held of Edward III in liege homage. ${ }^{57}$ Maintaining English rule in southern Scotland proved difficult, especially after Edward III declared war on France 
in 1337, but it was not until 1357 that the territorial integrity of Scotland seemed secure, although Berwick (formerly the richest burgh in the kingdom of the Scots) remained in English hands. ${ }^{58}$

These events occurred in interaction with the Plantagenets’ promotion of interests in continental Europe, which were normally accorded a higher priority than affairs within Britain or Ireland. In 1340 Edward III assumed the title 'king of France' and, by the mid1350s, he was claiming jurisdiction in all the constituent lands of the erstwhile 'Angevin empire’ ${ }^{59}$ His real administrative purchase was more limited. In 1279 Edward I became count of Ponthieu through his marriage to Eleanor of Castile (d. 1290), and the county was under English administration intermittently until $1369 .{ }^{60}$ After the siege of Calais in 1347, Edward III expelled the townsmen and installed a colony of English merchants. By the treaty of Brétigny (1360), which brought about a temporary cessation of hostilities, the French ceded Calais and the county of Guines to Edward III in full sovereignty; what became known as the 'Pale of Calais' was considered a parcel of the English crown, only to be lost in $1558 .{ }^{61}$ By the same treaty, Edward III also gained an enlarged Aquitaine in full sovereignty, making the status of the duchy until the fall of Bordeaux in 1453 analogous to that of Ireland or Wales, although the territorial gains of 1360 were lost soon after the resumption of war in 1369.

The real shift in the nature of the Anglo-French war occurred in the reign of Henry V, who followed up his victory at Agincourt with the full-scale invasion of Normandy beginning on 1 August $1417 .{ }^{62}$ The reduction of Normandy was largely complete by the late summer of 1419 - a stunning success that was only possible because of the fractiousness of a France riven between Burgundians and Armagnacs. ${ }^{63}$ The treaty of Troyes (1420) recognized Henry V as heir of Charles VI of France (r. 1380-1422), and the crowns of both kingdoms descended upon Henry VI in 1422 while he was still in the cradle. ${ }^{64}$ The flow and ebb of 
English power in France north of the Loire during the two decades of the precarious 'double monarchy' can be traced in the movement of the English-controlled financial offices. ${ }^{65}$ In January 1416 Henry V had appointed a treasurer of Harfleur, where a local exchequer operated according to English exchequer practice until 1420. With his full-scale invasion of Normandy underway, the king established a French-style chambre des comptes at Caen after the fall of the town in September 1417. This chambre was closed in 1424 when Normandy was placed under the authority of the chambre des comptes at Paris, now under English rule. ${ }^{66}$ When Paris fell to Charles VII of France (r. 1429-70) in May 1436, the English transferred the chambre back to the Norman capital of Rouen, where it remained until 1449 when the English abandoned the town, along with the financial records, to the French. ${ }^{67}$

\section{II}

\section{EMPIRE OF PARCHMENT, EMPIRE OF MEMORY}

'By virtue of our right we appointed our officials and ministers to govern the realm of Scotland', Edward I roundly informed Pope Boniface VIII in a letter of 1301 that sought to justify the use of overwhelming force to 'suppress the insolence' of his rebel subjects in Scotland. ${ }^{68}$ His protestation, specious though it was, underscores the point that the contribution of bureaucracy to empire was normative as well as instrumental. The king's right to appoint to the chief offices of his dominions was itself a demonstration of the legitimate possession—or 'effective occupation' to borrow the imperialist language of the Berlin conference of 1884-5—of the territory in question. Each of the dominions had its own potent traditions and customary laws, but there were structural similarities in their relationship to the crown. ${ }^{69}$ The common link was the person of the king, who from the mid-thirteenth century was normally resident in England and represented in the dominions by office-holders. At the head of each devolved administration was an omni-competent governor who acted in the 
place of the king himself: a seneschal in Gascony and Ponthieu; a justiciar in Ireland, and in north and south Wales; a warden in the Channel Islands. ${ }^{70}$

The main fault line in administrative practice ran between the continental possessions that followed French or local custom, and the king's lands within Britain and Ireland which approximated more closely to the structures and procedures of Westminster. The contrast is tangible in the surviving wax impressions of the seals that were used in each of the dominions to authenticate letters issued whether in response to mandates transmitted from Westminster or on the local initiative of the king's ministers. In the French lordships, the king's chief officer issued such letters in his own name and authenticated them not with a 'royal' seal but a seal of office: the 'seal of the court of Gascony' or the 'seal of the seneschal of Gascony'; ${ }^{71}$ the seal of the seneschal of Ponthieu; ${ }^{72}$ or the seals of the baillis of Jersey and Guernsey. ${ }^{73}$ This presents a contrast with the practice in the royal chancery of Ireland, ${ }^{74}$ and the smaller secretariats based at Caernarfon and Carmarthen, and at Berwick. ${ }^{75}$ The chancellor (or chamberlain in the case of north and south Wales) prepared letters in the king's name: these were attested by the king's representative (the governor, justiciar or keeper) and authenticated using a double-faced royal 'great seal' whose design was based on the great seal of England. ${ }^{76}$ (These 'deputed' great seals were the sigillographic forebears of the royal seals later to be employed in the crown colonies of British North America. $)^{77}$ The significance of this contrast in administrative form can easily be pressed too far: the king’s authority embraced all his dominions. At the formal condemnation of Llywelyn ap Gruffudd prince of Wales in November 1276, Edward I issued a mandate to all his subjects—in England, Ireland and Gascony_-inhibiting them from communicating with the Welsh or supplying them with victuals, horses or arms by land or sea. ${ }^{78}$ That the king's will, expressed through the written word and authenticated by his great seal of majesty, should run untrammelled throughout his dominions was articulated by Edward III in 1339: 'all his subjects are bound by their 
allegiance to obey his orders under the great seal of England. ${ }^{79}$ The existence in the dominions of seals subsidiary to the English great seal was clearly a matter of administrative convenience; but it was more than that. The deputed seal was the expression of the king's will and an icon of his regality (figs. 11.3-4).

[Figs. 11.3-4: English 'deputed' great seal for use in Ireland (1395), obverse and reverse, from the reign of Richard II. Reproduced by permission of Dublin City Archives. Photo Alastair Smeaton.

The images show the obverse and reverse of the wax seal attached by silken chords to a parchment royal charter granted to the city of Dublin in 1395 (Dublin City Archives, Royal Charter, no. 43). The front of the seal shows Richard II enthroned with the insignia of his kingship. The legend reads: RICARDVS DEI GRACIA REX ANGLIE ET FRANCIE ET D[OMI]N[V]S HIB[ERNIE] ET DUX AQ[UITANIE] ('Richard by the grace of God king of England and France, and lord of Ireland, and duke of Aquitaine'). The reverse displays the royal coat 'quartered' to display both the fleurs de lis of France and the lions of England.]

While the king might be corporally absent from the dominions, his authority was never in abeyance - although, in the case of Edward I, a more accurate sense of his personal feelings on the matter may be gauged by his (alleged) indecorous remark upon entrusting the seal deputed for the governance of Scotland to a newly-appointed lieutenant: 'A man does good work when he rids himself of a shit. ${ }^{80}$

Much of the routine documentation produced by the central administration concerned the dominions either directly or (in the case of preparations for war) indirectly. A change in record-keeping practices occurred early in the reign of Edward I to address the problems caused by this volume of business. The solution was to transcribe copies of outgoing letters concerning the dominions on rolls that took their name from the geographical areas in question. ${ }^{81}$ The first of these specialised compilations was the class of enrolments known as the Rotuli vasconie ('Gascon rolls'), which begin 1273-4 and continue to the reign of Edward IV. ${ }^{82}$ They set a precedent that was followed when the growth of English power in Wales 
justified the creation in 1277 of the short-lived Rotuli wallie ('Welsh rolls') which run until 1294. ${ }^{83}$ The Rotuli scotie (the so-called 'Scotch’ rolls), which form the longest such series in terms of chronology since they persist into the early Tudor era, began to be compiled in 1291: their first entry announces Edward I’s right as ‘sovereign lord of the realm’ of Scotland (F. sovereyn seignur du reume).$^{84}$ When Henry V launched his invasion of Normandy in August 1417, the chancery instituted a series of Rotuli normannie ('Norman rolls'). ${ }^{85}$ The lordship of Ireland stands outside this development in archival practice: English chancery letters concerning Ireland continued to be enrolled on the main series of English patent, close, charter and fine rolls. ${ }^{86}$ All these series of chancery enrolments contain transcripts of the outgoing post of the Westminster administration. To gain a complete picture of English recordproduction concerning the dominions we would need to aggregate several thousand more documents produced annually in the various devolved administrations of the empire. ${ }^{87}$ Truly this was an empire of parchment, not a parchment empire. ${ }^{88}$

Strategies of legitimation and super-ordination were embedded and encoded in the diplomatic formulae of these records. After Edward III assumed the title of king of France in 1340, letters issued in his name formally withheld from the (real) king of France the royal title and referred to him instead as ‘our adversary of France’ or, more resonantly, 'Philip of Valois who calls himself king of France'. ${ }^{89}$ During the Anglo-Scottish wars, the English chancery refused to acknowledge the kingship of Bruce family, styling King Robert I of Scots (r. 1306-1329) merely as 'Sir Robert de Bruce'. In 1328 Robert’s son, the future David II of Scots (r. 1329-71), married a daughter of Edward II (r. 1307-27), in consequence of which official records later referred to David not as king, but as 'our brother of Scotland' ${ }^{90}$ Even when the chancery grudgingly accorded the royal style to kings of Scots, the diplomatic etiquette which entitled a foreign monarch to be placed first in the opening protocols of royal letters were cast aside so that the king of England was granted priority. ${ }^{91}$ In Ireland, too, the 
chancery operated a form of bureaucratic disparagement by withholding the title 'king' from Gaelic lords, instead employing from the mid-fourteenth century terms such as nacionis sue capitaneus ('chieftain of his kindred') or insisting on a bare surname. ${ }^{92}$ The grandiose titles, such as princeps or $d u x$, that appear the submissions and letters received by King Richard II (r. 1377-99) in Ireland in 1395, served as a means of fixing provincial hierarchies within the Gaelic lordships without recognizing the Gaelic leaders as 'kings'. 93

Their combination of symbolic significance and practical utility meant that the records of colonial administration might themselves be the targets of agitation. During the revolt in 1294 of Madog ap Llywelyn (d. 1295), the Welsh broke into Caernarfon and slaughtered the king's ministers, burning the records housed in the exchequer. ${ }^{94}$ This was a symbolism that cut both ways. Conquest sometimes began with the ritual removal or destruction of records, as when Edward I transferred the muniments of Scotland to Westminster in $1296,{ }^{95}$ or when Henry V publicly burned the title deeds of Harfleur and Caen at their surrender in 1417 thereby erasing the memory of French administration. ${ }^{96}$

If memory could be erased, it might also be systematized. A potent aspect of bureaucracy as a buttress of imperial rule was its function as the 'strongbox of the empire'. ${ }^{97}$ It was, in other words, a source of written institutional memory, real or contrived-though few 'memories' were quite so brazenly invented as the forgeries produced by John Hardyng in the fifteenth-century purporting to prove the English claim to overlordship over Scotland. ${ }^{98}$ English record-keeping, as John Gillingham describes above, was precocious. The first recorded royal archivist occurs as early as $1215 .{ }^{99}$ But the accumulation of records soon outpaced the crown's ability to retrieve the information it required. Edward I declared to Boniface VIII that the English right to exercise superior lordship over Scotland was 'graven upon the tablets of our memory with an indelible mark'. ${ }^{100}$ In reality, the king's failure to discover relevant documents to support that claim within the royal archives exposed a 
weakness that he sought to remedy through the obsessive documentation of his dealings with Scotland from 1291. In 1296 Edward I recorded the submission of over 1,500 defeated Scots at Berwick, and he later commissioned a public notary to transcribe the submissions in triplicate on parchment scrolls known as the 'Ragman Rolls', which were deposited in the chancery, exchequer and wardrobe. ${ }^{101}$ It was a striking case of the bureaucratic mentality working overtime to make up for the shortcomings of precedent. ${ }^{102}$

During the reign of Edward II, the administration made efforts to improve its 'information retrieval' systems by copying and listing significant documents with the purpose of 'having a fuller memory of them in the future'. ${ }^{103}$ The compilations of this period have normally been ascribed to the class of English archives that deals with diplomatic administration, but that classification is only partially accurate. ${ }^{104}$ Large sections of the manuscripts were given over not to treaties and diplomatic relations with 'foreign' powers, but rather to the rights claimed by the Plantagenets in (what they viewed as) their own dominions. ${ }^{105}$ Already in the reign of Edward I, a codex known as Liber A-compiled in book form as a means of easy reference to loose documents held in the coffers of the exchequer — contained documents concerning, among other things, relations between the English crown and the rulers of Wales and Scotland. ${ }^{106}$ In Edward II's reign, the exchequer began a more thoroughgoing sortation of its records, together with the transcription or listing of documents into books. A Gascon 'register' (containing full transcripts) was completed in 1319, followed in 1322 by an inventory or 'calendar' of Gascon documents. ${ }^{107}$ These compilations were the prelude to a more general inventory overseen by the energetic treasurer of England, Bishop Walter Stapeldon (d. 1326), which was to include in summary form 'all letters, processes, instruments, and memoranda ... affecting the realm and the king's lands in Ireland, Wales, and Scotland'. ${ }^{108}$ The result, known as Bishop Stapeldon's calendar, was completed by $1323 .{ }^{109}$ The contents of the calendar are marked off by pictograms drawn in 
the margin corresponding to the devices (L. signa) painted on the chests or coffers in which the original documents were deposited in the exchequer. Many of these signa are simply armorial devices, but among those concerning Ireland and Wales are caricatures that play on ethnic stereotypes: an image of a Welsh archer or spearman identifies the chest containing records concerning Wales; a hooded warrior bearing an axe was marked on a chest containing the documents concerning Ireland. ${ }^{110}$ The imagery of ethnic difference, not to say the presumption of English cultural superiority, was embedded in the mnemonic devices of English record-keeping (see figs. 11.5-6). ${ }^{111}$

[Figs. 11.5-6. Illustrations of Welsh archer and Irish axeman from Liber $A$ (E 36/274, fos. 32 and 38r, TNA), late 13th cent. Reproduced by permission of The National Archives.]

The immediate spur for the creation of the exchequer compilations was the desire to improve and control the collection and disbursement of revenue. ${ }^{112}$ They also served a wider purpose. A compilation such as the 'Great Roll' concerning the English claim to Scotland made by the notary Andrew de Tange between 1315 and 1318 was clearly not an impartial record of events; it was a pièce justicative. ${ }^{113}$ In 1400 when Henry IV (r. 1399-1413) revived his claim to the overlordship of the Scottish kingdom as a prelude to a military campaign across the northern border, a series of documents concerning Scotland were removed from Liber A to provide the necessary evidence. ${ }^{114}$ In the next reign Henry V received ambassadors from the Scots to negotiate the release of their king, James I (r. 1406-1437), who had been in English captivity since 1406. Henry V took the opportunity to revive his claim to 'the submission, homage, and other peculiar rights due from of old to the crown of England from the kings of the Scots and their people', which (so his biographer tells us) were 'demanded of the king in accordance with lawful documents which are listed in a volume of 
records'. ${ }^{115}$ Records might also be used to jog the memory of a king who would have preferred to indulge in a convenient amnesia, as when the English settler population of medieval Ireland sought to saddle the crown with unsought military and financial commitments. In 1394-5 Richard II received a series of submissions from the lords of Gaelic Ireland which were recorded in writing by notaries. The deeds of submission were brought back to England and deposited in the chancery, while a transcript of all the 'public instruments, indentures and other muniments’ was enrolled among the memoranda of the English exchequer by order of the treasurer of England. ${ }^{116}$ In 1421, in an effort to prod Henry V into undertaking the 'final conquest' of the island, envoys from the Irish parliament (an assembly representative only of the settler population) reminded the king that these records were languishing in the royal treasury and requested that a crusade be launched against the Gaelic 'rebels' who had breached the terms of their submissions. ${ }^{117}$

III

\section{SPACE AND COMMUNICATIONS}

When the Spanish viceroy Don Antonio de Mendoza (d. 1552) quipped that 'Peru was the best place that the King of Spain gave, save that it was somewhat too near Madrid', ${ }^{118}$ he unwittingly pre-empted the 'spatial turn' in imperial studies, with its insistence that space is relative and is experienced relationally as well as in absolute terms. ${ }^{119}$ The bureaucrats in England's medieval empire were not menaced by the tyranny of distance so much as by their close monitoring from Westminster-far too close for the comfort of ministers suspected of peculation or those who were called to render accounts by the exchequer and pursued for their debts relentlessly, literally beyond the grave (through their executors) should they have the impertinence to die before being acquitted. ${ }^{120}$ 
The nodal points in crown's administrative network were the towns that accommodated the sedentary departments of dominion government, most importantly the local exchequers or treasuries at Dublin (and briefly Carlow); Berwick; Caernarfon and Carmarthen; Bordeaux; and the outpost of Calais which, among other its other advantages, provided a secure port for the passage of cross-channel communications. ${ }^{121}$ Messengers in the royal service received a fixed sum for regular journeys to these locations. In the midfourteenth century, ten shillings was the standard amount paid for carrying letters from Westminster to Dublin, the sum being increased if the messenger had to journey inland beyond the city. ${ }^{122}$ The speed of communications between Westminster and these local ‘capitals’ was variable, but in most cases (assuming good conditions and a feeling of urgency $^{123}$ ) the time in which a messenger might be expected to deliver the king's writs would be measured in weeks, and nothing like the minimum of two or three months that it took for an outbound Spanish fleet to cross the Atlantic in the sixteenth century, let alone the twelve months it took to reach the Philippines. ${ }^{124}$ In April 1322 it took thirteen days for the records of the exchequer to trundle from Westminster to their new accommodation in the castle of York: the pace of approximately twenty miles per day was fair given that the journey was slowed by the carriage of all the records of the office, which were stored in specially-commissioned wine chests. ${ }^{125}$ In July 1455 news of the relief of Berwick from the Scots was carried the longer distance from Newcastle to London in six nights; while in 1482, Edward IV initiated a relay system with riders stationed at intervals of twenty miles so that a letter passed at the rate of 200 miles in two days. ${ }^{126}$ Sea travel was less certain. One prominent Irish prelate who was no stranger to travel between Ireland, England and Rome preached that he had known of men who had to wait in an English port from the feast of St John (24 June) until after Christmas for a favourable crossing to Ireland. ${ }^{127}$ In fair weather, the crossings could be accomplished in a single day (by comparison Bordeaux was four or 
five days’ distant from the southern English ports), and the administration at Westminster could expect that a mandate transmitted to Ireland would reach its destination and be acted upon within six or eight weeks of its issue. ${ }^{128}$

Land routes radiating outwards from London are depicted on the remarkable 'Gough map’, the earliest surviving map of Britain in which the island appears in recognizable form, dating from the second half of the fourteenth century (though possibly based on a late thirteenth-century original). ${ }^{129}$ Its most recent interpreters emphasize the positional accuracy with which the main settlements are plotted, which would have made the map useful in estimating distance and travel times. ${ }^{130}$ Pictographic 'vignettes’ depict Dublin, Berwick, Carmarthen and Calais as walled towns - an indication of the strategic or political significance they were accorded by the makers of the map, who may have been agents of the royal administration. ${ }^{131}$ From the vantage-points of their parapets, these local 'capitals' must have seemed like the local hubs of 'central' government; but it is useful to invert the perspective. Colonial towns were often ethnically and geographically liminal, being English enclaves perched precariously on the peripheries of the societies they were supposed to dominate, their heavy fortifications betraying a sense of insecurity even while seeking to convey the dread power of the king. Projecting administrative will from the castles that clung to the coast of north Wales into the mountainous interior, or from lowland Berwick into the vastnesses of the Scottish highlands, was highly problematical. It may be no coincidence that these mountains are among the few relief features to be depicted on the Gough map. ${ }^{132}$ From 1361 until 1394 the Irish exchequer was relocated from Dublin to the inland town of Carlow in an effort to provide better access to the south and south-west of the island. The experiment failed. The Gaelic lords of Leinster repeatedly attacked the town. ${ }^{133}$ Richard Walsh, a midranking parchment pusher in the Irish administration, pleaded to the crown in 1392 for recompense in consideration of his forty years of service in the chancery and exchequer of 
Ireland: 'now in his old age', so his petition ran, he had been 'ruined for the rest of his days' because his property had been burned and destroyed by the king’s 'Irish enemies'. ${ }^{134} \mathrm{~A}$ cultural gulf might separate agents of the crown and the native population, even when in absolute terms they were thrust up against each other, cheek by jowl.

A different aspect of the 'relationalization' of imperial space is suggested by the shuffling of bureaucrats around the dominions. The medieval 'English world' was scarcely global in its extent, but it was geographically dispersed and bureaucrats on the move served to shrink it to manageable, or at least imaginable, proportions. ${ }^{135}$ In 1293 the treasurer of Ireland and the constable of Bordeaux — the chief financial officers in Ireland and Gascony respectively_-were mentioned in the same breath in the order specifying that 'henceforth each year the account of Gascony and Ireland shall be rendered at the English exchequer and there audited by the king's treasurer and barons'. ${ }^{136}$ Audits of the Irish exchequer did not in fact take place annually, but once the process was put in train (as happened every few years, and certainly at the end of a term of office) both the Irish treasurer and a chamberlain travelled to Westminster with duplicate sets of their accounts, together with ancillary supporting documentation, for scrutiny before the barons of the English exchequer. ${ }^{137}$ The result was a periodic traffic of people and parchment between core, periphery, and back again. Less obvious, but perhaps more important in terms of binding the empire together, was the circulation of ministers between dominions. ${ }^{138}$ Robert Power served as the king's escheator in north and south Wales, and later as chamberlain of north Wales. ${ }^{139}$ In January 1325, while chamberlain, Power sent to Ireland for corn and other supplies for the king's castles in north Wales. ${ }^{140}$ Two years later, he was transferred to Ireland, where between 1327 and 1331 he served as treasurer. In 1333 he was in Scotland and was rewarded for his service at the siege of Berwick. Unlike two other treasurers of Ireland, Thomas Burgh and John Bolton, who became chamberlains of Berwick, Power returned to Ireland, where he served as 
a baron (and later chief baron) of the Irish exchequer until $1344 .{ }^{141}$ Peripatetic careers such as his were not restricted to circuits of the king's dominions in Britain and Ireland. In the last decades of the fourteenth century, two successive archbishops of Dublin who held office as chancellor of Ireland had earlier seen service in Gascony: Robert Wikeford (d. 1390) as constable of Bordeaux; ${ }^{142}$ and Robert Waldby (d. 1397) as keeper of the seal for the seneschal of Aquitaine. ${ }^{143}$ Few were perhaps as mobile as William Allington (d. 1446), whose early service was as receiver of the English garrison at Brest (1397) and treasurer of Calais (1398). In 1403 Henry IV appointed him as treasurer of Ireland, a post Allington held for much of the next decade. On 1 May 1419, he became treasurer-general of the duchy of Normandy and the pays du conquête. So important were these administrative roles to Allington's sense of personal prestige that his memorial brass in the church at Horseheath (Cambs.) described him as sometime treasurer of Ireland and Normandy. ${ }^{144}$

The aspect of communications that has been more intensively studied than any other is the logistical organization of war, which is minutely documented in the records of the royal bureaucracy. It was England's skill in military logistics that Tito Livio Frulovisi memorialised in his Life of Henry V (c.1438):

They lacked neither mines to undermine the ground, nor carpenters to make and raise [siege] engines, nor labourers to delve the ground and to lade ditches, nor masons to hew stones for shot to break walls, to subvert strongholds, nor gunners to shoot the guns ... ${ }^{145}$

This is stirring stuff, but we require a sense of proportion. Frulovisi was writing retrospectively 'with the stench of decline hanging in the air' in the aftermath of the Congress of Arras (1435), when the Burgundians deserted the cause of the English in France. ${ }^{146}$ More generally, the history of military administration carries with it the risk of adopting the quarter-master's view of the subject. Christine Carpenter has recently urged that '[England’s] 
bureaucratic heroes need to be studied alongside the military heroes whose great deeds they made possible'. ${ }^{147}$ The subject matter is certainly important, but the note of triumphalism may be somewhat premature. Arguably, the greatest test faced by bureaucrats was not so much the organization of war, ${ }^{148}$ but the conversion of a military campaign into regular civil administration — in other words bridging the gap between 'conquest' and 'empire'. ${ }^{149}$

\section{EMPIRE OF DIFFERENCE}

A more sober assessment of the capacities of the English state to bridge that gap was offered by R. R. Davies in a series of influential publications. Drawing on the categories of Max Weber, Davies distinguished the 'patriarchal and tributary' character of the English state and its relations with the 'Celtic' peripheries in the eleventh and twelfth centuries from an increasingly 'bureaucratic and integrative' approach discernable in the thirteenth century. ${ }^{150}$ With bureaucracy arose a 'mentality of uniformity' promoted by and grounded in the growth of written records as a medium of English governance: 'Once the steam-roller of uniformity was on the road nothing was to be allowed to stand in its way. ${ }^{, 151}$ Davies reserved his most scathing remarks for the new breed of bureaucrats who were 'the advocates of uniformity; indeed without uniformity their world is shattered, their authority undermined' ${ }^{152}$ This bureaucratic insistence on uniformity of rule portended a failure of governmental control and political imagination that 'disabled [England] from reaching out effectively and constructively to the other peoples and power centres of the British Isles, except possibly on its own terms' ${ }^{153}$ Consequently, in his Ford lectures of 1998 on the 'first English empire' Davies chose to date the 'ebb tide' of empire to the early fourteenth century, by which time the limits of integration within Britain and Ireland were apparent. ${ }^{154}$ On this point, somewhat ironically, Davies's views were consonant with those of an earlier Ford lecturer, namely T. F. 
Tout, founder of the very school of administrative history whose accumulated interpretation of 'the pretensions and the capaciousness of the English state' Davies subjected to such searching re-interpretation. ${ }^{155}$ In the 1913 Ford lectures on the 'place of Edward II in English history', Tout identified the early fourteenth century as marking a shift away from 'what we may by anticipation call imperial history' because it witnessed the 'collapse of the imperialistic visions of Edward I'. ${ }^{156}$

Significantly, there is a degree of conceptual slippage or inadvertent conflation in these interpretations between 'empire' and the idea of an integrated, uniformly-ruled 'state'. ${ }^{157}$ There is little, in fact, to suggest that it occurred to Edward I-or, for that matter, any other late-medieval English king — to shoehorn Wales or Scotland, let alone the dominions outside the island of Britain, into a ‘single, united, England-centred kingdom' or state, even had they been able to. ${ }^{158}$ By considering England's insular and continental possessions together as a concatenation, an interlinked whole, their cardinal feature appears to be 'organized diversity', rather than rigid uniformity. ${ }^{159}$ The devolved administrations were kept separate and subordinate. Delegation and accountability were the order of the day; integration and incorporation were not-at least until the passage of the so-called 'Act of Union' between England and Wales in 1536. But if the reversals that the English experienced in the first quarter of the fourteenth century were not really a 'failure' of state-making, they might possibly be understood as a symptom of the unstable dynamics of empire-building that persisted into the fifteenth century. In that light, the disjunction that Davies identified between 'state power' and 'indigenous “political” society’ is a key insight whose application can be extended, perhaps with even greater application, into the late Middle Ages. ${ }^{160}$

Within England, a broadening of political society during the fourteenth century resulted in the cooptation of the crown's middling landholders in the administration of justice in the English localities. ${ }^{161}$ It was precisely this alliance between the royal bureaucracy and 
local elites that was difficult to replicate in a stable fashion among populations that viewed English-appointed officials with attitudes ranging from suspicion to outright hostility. During the revolt of Owain Glyn Dŵr (c.1359-c.1416) in the first decade of the fifteenth century, a letter from Prince Henry (the future Henry V) concerning the killing and murder of his loyal servitor and officer refers to the fact that the Welsh rebels wished to see to it that no Englishman should hold office in Wales. ${ }^{162}$ Of course, within England itself, the royal administration was the subject of a large literature of complaint, ${ }^{163}$ and individual ministers occasionally fell victim to popular agitation. In the dominions, however, bureaucratic ‘efficiency’ and activity—as measured by the ability to intrude and extract—could prove the undoing of English rule. The classic case is that of Hugh Cressingham, that 'busy man on the spot’ as G. W. S. Barrow memorably described him, whose vigour as treasurer of Scotland may have hastened the demise of English rule in Scotland in 1296-7. ${ }^{164}$ The very title of Cressingham's office was an affront to the Scots, who referred to him not as the king's treasurer, but as the 'treacherer' (L. non thesaurarium sed traiturarium regis). Before the kingship of John Balliol (r. 1292-6), the officer charged with the financial administration of Scotland was the chamberlain. The title 'treasurer' was an English innovation and, like Cressingham himself, short-lived. After Cressingham's death at the battle of Stirling Bridge in 1297, the Scots expressed their contempt by flaying his body and dividing the skin between themselves. ${ }^{165}$

Edward I's response to the shock defeat of his army at Stirling was to let loose all the financial and military resources at his disposal. By 1304 he had bludgeoned the Scots into submission. A new governmental dispensation issued in 1305- 'The ordinance for the good order of Scotland'—envisaged an administration less uncompromisingly English in character and composition than the short-lived administration based at Berwick in 1296-7. The ordinance specified that the four chief officials in Scotland (lieutenant, chancellor, 
chamberlain and controller) were all to be Englishmen, but to enforce justice four pairs of officials were nominated, each pair comprising an Englishman and a Scot. The local administrative office of sheriff could be occupied either by men born in either Scotland or England, and although the power of appointment lay with the king's lieutenant (with the exception of the sheriffdom of Berwick, which was in the gift of the chamberlain of Berwick) a preponderance of Scots filled the sheriffdoms outside the lowland territories. ${ }^{166}$ Whether the disposition of Scotland as set out in 1305 would been viable cannot be known. Robert Bruce seized the throne of Scotland in 1306-7, and the further brutalities that Edward I unleashed upon his Scottish 'rebels' in response stiffened resistance to English rule into a movement of national independence. ${ }^{167}$

The compromises of the 1305 ordinance, inadequate as they may have been, were an acknowledgement of what should have been obvious in the first place: the necessity of working with the grain of local political society. In the Plantagenet lands in France, the Englishness of bureaucracy typically ran quite shallow. The hierarchy of officials in the county of Ponthieu adhered to a French pattern, with an administration headed by a seneschal supported by a receiver and controller, and five local baillis. Englishmen served the three Edwards as seneschal of Ponthieu, but the receiver was customarily a Pontevin until the reign of Edward III, who appointed English clerks. ${ }^{168}$ In Gascony, similarly, the highest officesthe seneschal, and the constable and mayor of Bordeaux — were normally reserved for Englishmen or non-Gascons, who were actually preferred by the Gascon population because they were perceived as impartial. ${ }^{169}$ The vast majority of lesser officials—-the sub-seneschals, prévôts and baillis — were Gascons, whose first language was not French (with which the English were conversant) but Gascon. ${ }^{170}$ The local chancery accommodated this by routinely producing formal documents in the local vernacular. ${ }^{171}$ In this light, the policy of Edward the Black Prince (d. 1376) during his residence in the enlarged principality of Aquitaine (1363- 
71) stands out as exceptional. The prince appointed ‘pure English' men even to the lesser offices, and not only in Gascony but across regions that had, until the treaty of Brétigny, owed their allegiance to the king of France. This caused mounting resentment among the local nobility. The imposition of a fouage (hearth tax) in 1368 offered the excuse for a revolt in 1368-9 that quickly pushed effective English rule back to its traditional heartland around Bordeaux. ${ }^{172}$ It was an object lesson in the virtue of salutary neglect.

Even in Normandy, which Henry V took by conquest and pinned down by a landed settlement that favoured English proprietors, the king was anxious to present himself as a rightful ruler and he promised to receive those Normans who would submit to him as his loyal subjects. ${ }^{173}$ The English conciliated the Norman population by ruling through existing institutions or by reviving old ones, such as the ancient office of seneschal of Normandy and (at least between 1417 and 1424) the Norman chambre des comptes, both of which had fallen into abeyance under French rule since 1204. ${ }^{174}$ At local level in civil (as opposed to military) administration, English officialdom was a veneer. It was nearly always an Englishman who held the office of bailli in each of the eight Norman bailliages, but the form of administrative practice was Norman and the lower offices of local administration were nearly all occupied by Frenchmen. ${ }^{175}$ John duke of Bedford deliberately cultivated the local significance of the vicomte precisely because the vicomtes were normally Frenchmen who played a key role in summoning the 'estates of Normandy' - the representative assembly, almost entirely French in composition, empowered to vote subsidies in support of the English war effort. ${ }^{176}$ The heavy reliance on local collaborators made English rule in northern France vulnerable, especially when the tide began to turn against them: as Juliet Barker observes, 'it was hardly surprising that fear of treachery haunted the Lancastrian administration'. ${ }^{177}$ But a new regime also offered new opportunities. The career of Louis de Luxembourg (d.1443) provides an illustration of how high a non-English minister might rise. Louis was a Burgundian whose 
service to the English brought him to the pinnacle of administrative power in occupied France. In 1425 he received the office of chancellor of France for the English; by 1433 he was related to the royal kin through the marriage of his niece Jacquetta to John of Bedford, in whose stead Louis served in 1433 as regent—-the supreme position in the government of 'English' France. It was shortly after this that the anonymous bourgeois of Paris recorded in his journal that, among the people of Paris, Louis was 'more hated and cursed than ever the Emperor Nero was'. ${ }^{178}$ Louis’s personal fortune was now bound up with the English. Forced to flee Paris in 1436 when the city fell to the French, he was jeered by the citizens. In 1437 Louis sought and was granted a charter of denizenship, which paved the way for a run of preferment in lands and benefices (including the diocese of Ely in commendam) in England, granted in compensation for his losses in France. ${ }^{179}$

Louis de Luxembourg found it possible to assimilate to the English without the need of acculturation because he shared in a wider world of Western European culture that the English considered 'civilized'. The obstacles thrown up against the native population in the principality of Wales were more difficult to overcome. The Welsh faced ethnic discrimination and legal disabilities, notably in the ordinances issued in 1295 after the revolt of Madog ap Llywelyn, which forbade the native Welsh from purchasing or residing in the walled towns of the principality. ${ }^{180}$ Nevertheless, since the generation after the conquest of Wales, the English had relied upon native Welsh to fill local offices, not least because they spoke Welsh. ${ }^{181}$ Members of the uchelwyr, or native Welsh squirearchy, were soon drawn into the ambit of English administration in the principality, even while patronising a native literary tradition of Welsh bardic poetry that was guardedly hostile to English overlordship. ${ }^{182}$ As David Johnston has commented of the Welsh poetry of Iolo Goch, the bard of (among others) Owain Glyn Dŵr: ‘The crucial condition of Iolo’s acceptance of English rule was that Welshmen should hold influential office in local government in order to 
ensure the just treatment of the Welsh people. When that condition was not fulfilled tension appeared in his poetry.' ${ }^{183}$ The normal situation was one of co-operation punctuated 'by periodic spasms of racial hatred and rebellion'. ${ }^{184}$ The exclusion of the native Welsh from administrative office was only placed on a statutory footing in response to the revolt of Owain Glyn Dŵr, following which the English parliament enacted that no Welshman was to be appointed 'justiciar, chamberlain, chancellor, treasurer, sheriff, steward, constable of castle, receiver, escheator, coroner nor chief forester, nor other officer, nor keeper of the records, nor deputy in any of the said offices in any part of Wales’. ${ }^{185}$

So far as a 'native policy' is concerned, colonial Ireland is a case of the dog that did not bark. In one sense, it was the most mundanely English of the dominions, with a departmentalized administration closely modelled on English administrative practice. ${ }^{186}$ The Englishness of colonial Ireland was also thoroughgoing in another, perhaps more sinister, sense. As John Gillingham discusses above, King John formally extended English law to the lordship of Ireland in $1210 .{ }^{187}$ As a result, in contrast to Wales, the native population of Ireland came to be entirely excluded (with trifling exceptions) from lay political society within the English colony. ${ }^{188}$ The Gaelic Irish could not hold land in Ireland by English tenures and were unable to plead in the king's courts. This meant that they could not participate in the English administration of Ireland, even at the lowermost levels of local government. ${ }^{189}$ 'Irish' bureaucrats were either born in England or born in Ireland but English by descent. But to conclude that Ireland was a 'little England beyond the sea' would be seriously misleading. ${ }^{190}$ English institutions proved relatively durable in the fertile lowlands, where a substantial settler population served the crown in war and local administration, and sometimes made a nuisance of itself to English-born chief governors. ${ }^{191}$ But across the greater part of the country, the royal administration faced difficulties in routinizing its authority. Even as the royal government reached its zenith in Ireland in the mid-1290s, the 
administration's ability to raise revenue on the basis of a lay subsidy assessed at the level of the household was limited mostly to the south and east, where the economy was manorialized and conditions were peaceful. This was an indication of the difficulty of extending Englishstyle rule outside those areas that were ethnically or topographically predisposed to accept it. ${ }^{192}$ The problems only became more severe after the economic and demographic collapse of the early fourteenth century. In this sense, the 'attempt at recovery' of the later fourteenth century was wildly optimistic in what it thought it could achieve. ${ }^{193}$ In 1361 Edward III packed his son Lionel (d. 1368) off to Ireland with an army funded by the English exchequer with the aim of returning the lordship to profitability and, by implication, restoring regular administration. ${ }^{194}$ The policy was doomed to failure before it began because its operating principle was the unyielding extension of English norms, when it was precisely the refusal to fold the native population within its structures that made bureaucracy in colonial Ireland so brittle in the first place. The origins of the Irish 'Pale' are to be found in this state of mind.

Empires are often successful at unleashing military force, whether in pursuit of territorial conquest or to discipline rebellious subjects; they find it more difficult to exercise power sustainably over long periods of time. ${ }^{195}$ In the case of the 'first English empire' this contrast between 'force' and 'power' is found in an intensified form. The formidable capacity of England's bureaucracy to marshal resources and men for the purposes of waging war is scarcely in doubt. As Ifor Rowlands remarked of the Edwardian conquest of Wales: 'Welsh independence did not as much perish in a clash of arms as suffocate in a welter of parchment. ${ }^{196}$ But given the scale of the resources that they had at their disposal, it is surely 
the setbacks that the bureaucrats experienced—and sometimes provoked—-that is most striking.

Part of the explanation for the brittleness of bureaucracy, I have sought to argue, lies in the structuration of the bureaucracy itself. Little could be achieved by English officials without the cooperation or compliance of power-brokers within indigenous political societies. In the French dominions, and to a degree also in Wales, collaborative elites made Plantagenet rule viable even while rendering it intensely vulnerable. English officials in these dominions would have been no stranger to what Bruce Berman described, in quite another context, as the oscillation between control and crisis: 'between a commanding sense of volitional power and a fearful sense of impotence in the face of unseen and incomprehensible forces. ${ }^{197}$ The settlers of English Ireland were, of course, like settlers everywhere, the 'ideal prefabricated collaborators', especially since (unlike the Gascons) they had no source of alternative allegiance to which they might appeal over the head of the English king. ${ }^{198}$ Gaelic Ireland was another story. Power sharing was not merely a concession to pragmatics; it was constrained also within the mental horizons of the rulers. Where the English official mind refused to countenance any indigenous intermediacy, there it proved hardest to achieve stable imperial rule. To that extent, white or Anglophone settler colonialism, which consigned native peoples to oblivion through its exterministic agenda, was the 'solution' to a problem that the English encountered but chose not to confront in Ireland during the late Middle Ages. $^{199}$

\footnotetext{
${ }^{1}$ My title recalls David Fieldhouse’s much-cited essay, 'Can Humpty Dumpty be put together again? Imperial history in the 1980s', JICH 12:2 (1984), 9-23.

${ }^{2}$ Koebner, Imperialism, p. 136. The idea that Britain was a 'most peculiar' empire also occurs in John Campbell’s Political survey of Britain (1774), cited by Greene, below, p. + n. 12.
} 
${ }^{3}$ For these complexities, see Robin Frame, 'Kingdoms and dominions at peace and war', in Ralph Griffiths (ed.), The short Oxford history of Britain: the fourteenth and fifteenth centuries (Oxford: Oxford UP, 2003), pp. 150-7. For the varying status of king’s subjects, see Ralph Griffiths, 'The English realm and dominions and the king's subjects in the later Middle Ages', in Griffiths, King and country: England and Wales in the fifteenth century (London and Rio Grande: Hambledon, 1991), pp. 33-54; Andrea Ruddick, English national identity and political culture in the fourteenth century (Cambridge: Cambridge UP, 2013), ch. 5.

${ }^{4}$ Franchises or liberties (areas immune from the normal jurisdiction of the crown) were a commonplace: see below, n. 79.

${ }^{5}$ Michael Brown, Disunited kingdoms: peoples and politics in the British Isles, 1280-1460 (Pearson, 2013), who notes that the conquests of the English crown 'did not result in the secure establishment of an "English empire" , (quotation at p. 69).

${ }^{6}$ Cf. Ged Martin, 'Was there a British empire?', HJ 15:3 (1972), 562-9.

${ }^{7}$ I consider other overarching political structures, including the royal dynasty and aristocratic estateholding, in Peter Crooks, 'State of the union: perspectives on English imperialism in the late Middle Ages’, P\&P 212 (2011), esp. 8-17.

${ }^{8}$ J. N. Hillgarth, The problem of a Catalan Mediterranean empire, 1229-1327 (London: Longman, 1975); David Abulafia, A Mediterranean emporium: the Catalan kingdom of Majorca (Cambridge: Cambridge UP, 1994). Sally McKee discerns some similarities between England’s overseas bureaucracy and the rule of Crete by Venice in McKee, Uncommon dominion: Venetian Crete and the myth of ethnic purity (Philadelphia: University of Pennsylvania Press, 2000), esp. pp. 13-18. ${ }^{9}$ An important exception is John Le Patourel, 'The Plantagenet dominions', Le Patourel, Feudal empires: Norman and Plantagenet (London: Hambledon, 1984), esp. pp. 302-6; John Le Patourel, 'L'occupation anglaise de Calais au XIV siècle', in ibid., ch. 14. See also Robin Frame, The political development of the British Isles, 1100-1400, 2nd edn (Oxford: Clarendon Press, 1995), ch. 2 ('Empires, continental and British'), and pp. 138-41. Kenneth Fowler traces the lineaments of a 'politique impériale’ in his study of vice-regal office-holders: Fowler, 'Les lieutenants du roi 
d'Angleterre en France à la fin du moyen âge', Actes des congrès de la Société des historiens médiévistes de l'enseignement supérieur public, 29e congrès (1998), 193-205, at 203.

${ }^{10}$ Davies, Empire; see also Davies, Domination. On the need to bring the continental dominions into the analysis, see Robin Frame in 'Overlordship and reaction, c.1200-c.1450', in Frame, Ireland and Britain, 1170-1450 (London and Rio Grande: Hambledon, 1998), ch. 10, esp. pp. 181-90; Andrea Ruddick, 'Gascony and the limits of medieval British Isles history', in Brendan Smith (ed.), Ireland and the English world in the late Middle Ages: essays in honour of Robin Frame (Basingstoke: Palgrave Macmillan, 2009), pp. 68-88.

${ }^{11}$ See above, n. 9. For recent work in this vein, see W. M. Ormrod, 'The English state and the Plantagenet empire, 1259-1360: a fiscal perspective', in J. R. Maddicott and D. M. Palliser (eds.), The medieval state: essays presented to James Campbell (London: Hambledon, 2000), pp. 197-214; David Green, 'Lordship and principality: colonial policy in Ireland and Aquitaine in the 1360s’, Journal of British Studies 47:1 (2008), 3-29; Crooks, 'State of the union'; and Peter Crooks, David Green and W. M. Ormrod (eds.), The Plantagenet empire, 1259-1453 (Stamford: Shaun Tyas, 2016). For an earlier period, see David Bates, The Normans and empire (Oxford: Oxford UP, 2013).

${ }^{12}$ For a compendium of relevant constitutional documents, see A. F. Madden and D. K. Fieldhouse (eds.), The empire of the Bretaignes, 1175-1688: the foundations of a colonial system of government (Westport and London: Greenwood, 1985).

${ }^{13}$ Julius Goebel, 'The matrix of empire', Appeals to the Privy Council from the American Plantations by Joseph Henry Smith (New York: Columbia UP, 1950), pp. xiii-lxi.

${ }^{14}$ Ibid., p. xiv.

${ }^{15}$ A. F. McC. Madden, '1066, 1776 and all that: the relevance of English medieval experience of “empire” to later imperial constitutional issues’, in Gerald S. Graham, John E. Flint and Glyndwr Williams (eds.), Perspectives of empire: essays presented to Gerald S. Graham (London: Longman, 1973), pp. 9-26, at p. 9.

${ }^{16}$ For historiographical comment, see Andrew Thompson, 'Is Humpty Dumpty together again? Imperial history and the Oxford history of the British Empire', Twentieth Century British History 12:4 
(2001), 511-27; Douglas M Peters, 'Is Humpty Dumpty back together again? The revival of imperial history and the "Oxford history of the British empire” ', JWH 13 (2002), 451-67.

${ }^{17}$ Nicholas P. Canny (ed.), OHBE, vol. I: The origins of empire: British overseas enterprise to the close of the seventeenth century (Oxford: Oxford UP, 1998). The same chronology is observed in Kevin Kenny (ed.), Ireland and the British empire (Oxford: Oxford UP, 2004). Note, however, that there are some observations on the medieval antecedents of the later British empire in John Darwin's recent volume: Unfinished empire: the global expansion of Britain (London: Allen Lane, 2012), pp. $13-16$.

${ }^{18}$ See Greene, below, pp. ++.

${ }^{19}$ John H. Elliott, 'Empire and state in British and Spanish America', in Serge Gruzinski and Nathan Wachtel (eds.), Le nouveau monde, mondes nouveaux: l'expérience américaine (Paris: Editions recherche sur les civilisations and Editions de l'Ecole des Hautes Etudes en Sciences Sociales, 1996); Elliott, Empires.

${ }^{20}$ Robin Frame, 'Rediscovering medieval Ireland: Irish chancery rolls and the historian’, Proceedings of the Royal Irish Academy 113 (2013), 14.

${ }^{21}$ See introduction, above, p. ${ }^{++}$.

${ }^{22}$ Mary Aquinas Devlin (ed.), The sermons of Thomas Brinton, bishop of Rochester (1373-89), CS, 3rd series, LXXXV-LXXXVI (London, 1954), vol. I, p. 47.

${ }^{23}$ F. ses seignouries, terres, villes et fortz depar dela ( 'Richard II: October 1378', item 18, PROME);

F. terres et seignouries depar dela ('Richard II: January 1380', item 10, PROME); F. les seignuries du roy pardela ('Richard II: September 1397’, item 11, PROME).

${ }^{24}$ Gaines Post, ‘Two notes on nationalism: II. Rex imperator’, Traditio 9 (1953), 296-320. Brian

Tierney, ‘Bracton on government’, Speculum 38:2 (1963), 295-317; Fritz Schulz, 'Bracton on kingship', EHR 60:237 (1945), 136-76.

${ }^{25}$ Frank Taylor and John S. Roskell (eds.), Gesta Henrici Quinti: The deeds of Henry the Fifth (Oxford: Oxford Medieval Texts, 1975), pp. 112-13. When John duke of Bedford, regent of Henry VI in France, entered Paris in 1424, an anonymous citizen remarked that 'more honour was never done at 
a Roman triumph than was done that day to him and his wife' (Janet Shirley (ed.), A Parisian journal, 1405-1449, translated from the anonymous Journal d'un bourgeois de Paris (Oxford: Oxford UP, 1968), p. 201).

${ }^{26}$ The aims and methodology of a major collaborative venture to investigate this theme are described in Jean-Philippe Genet, 'La genèse de l'état moderne’, Actes de la recherché en sciences sociales 118 (1997), 3-18. In a very different historiographical tradition, see Joseph R. Strayer, On the medieval origins of the modern state, new edn (Princeton: Princeton UP, 2005). A more subtle to the formation of 'polities' amid the 'political convulsion' of the late Middle Ages is John Watts, The making of polities: Europe, 1300-1500 (Cambridge: Cambridge UP, 2009).

${ }^{27}$ On national identify, see Ruddick, English national identity; David Green, 'National identities and the Hundred Years War', in Chris Given-Wilson (ed.), Fourteenth Century England VI (Woodbridge: Boydell, 2010), both of which are better on the medieval evidence than Adrian Hastings, The construction of nationhood: ethnicity, religion and nationalism (Cambridge: Cambridge UP, 1997).

${ }^{28}$ The following is merely a representative sample: G. L. Harriss, 'Medieval government and statecraft', $P \& P 25$ (1963), 8-39, at 30 ('It is difficult to see why [English medieval government] should not be termed a fully bureaucratic system’); Michael Prestwich, ‘English government records, 1250-1330', in Richard Britnell (ed.), Pragmatic literacy, east and west, 1200-1330 (Woodbridge: Boydell and Brewer, 1997), p. 95 ('Medieval England, by the thirteenth century, was a highly bureaucratic country'); Ifor Rowlands, ‘The Edwardian conquest and its military consolidation', in Trevor Herbert and Gareth Elwyn Jones (eds.), Edward I and Wales (Cardiff: University of Wales Press, 1988), p. 48 ('During the thirteenth century, England became a truly bureaucratic country’); Ralph A. Griffiths, 'Public and private bureaucracies in England and Wales in the fifteenth century', in Griffiths, King and country, 137-59.

${ }^{29}$ T. F. Tout, 'The English civil service in the fourteenth century’, BJRL 3 (1916-17), 185-214, at 192-3. An excerpt from this essay is published under the title 'The emergence of a bureaucracy', in Robert K. Merton, Ailsa P. Gray, Barbara Hockey and Hanan C. Selvin (eds.), Reader in bureaucracy (The Free Press: Glencoe, 1952), pp. 68-9. 
${ }^{30}$ Weber's influence is more readily admitted in European scholarship: see the discussion by Patrice Mann, 'La genèse de l'état moderne: Max Weber revisité', Revue francaise de sociologie 41:2 (2000), $331-44$.

${ }^{31}$ W. M. Ormrod, 'Competing capitals? York and London in the fourteenth century', in S. Rees Jones, Richard Marks and A.J. Minnis (eds.), Courts and regions in medieval Europe (Woodbridge, 2000), pp. 75-98.

${ }^{32}$ A vast literature is admirably surveyed in Christine Carpenter, 'War, government and governance in England in the later Middle Ages', in Linda Clark (ed.), The fifteenth century VII: conflicts, consequences and the crown in the late Middle Ages (Boydell: Woodbridge, 2007), ch. 1. For an older survey, see S.B. Chrimes, An introduction to the administrative history of mediaeval England (Oxford, 1952), esp. pp. 129-43. On the authority of the privy seal and signet to 'move' the great seal, see B. Wilkinson, 'The authorisation of chancery writs under Edward III', BJRL 8 (1924), 107-39; A. J. Otway-Ruthven, The king's secretary and the signet office in the XV century (Cambridge, 1939). ${ }^{33}$ A.L. Brown, The governance of late medieval England, 1272-1461 (London, 1989), ch. 3. For more detailed studies, see B. Wilkinson, The chancery under Edward III (Manchester, 1929), who prints the ‘Ordinaciones cancellarie’ as appendix VI (whence EHD, vol. IV, no. 312, at pp. 499-500). ${ }^{34}$ Janice Gordon-Kelter, 'The lay presence: chancery and privy seal personnel in the bureaucracy of Henry VI', Medieval Prosopography 10 (1989), 53-74, shows that lay clerks constituted only a significant minority in the reign of Henry VI (r. 1422-61). For the shift towards lay predominance by the reign of Edward IV (r. 1461-83), see Charles C. Smith, 'Some trends in the English royal chancery: 1377-1483’, Medieval Prosopography 6 (1985), 69-94.

${ }^{35}$ Janice Gordon Richter, 'Education and association: the bureaucrat in the reign of Henry VI', Journal of Medieval History 12 (1986), 81-96.

${ }^{36}$ For samples documents with propagandistic purpose, see Chaplais, English medieval diplomatic practice, vol. I, pp. 422-64; and see G. P. Cuttino, 'King’s clerks and the community of the realm', Speculum 29:2 (1954), 395-409, for the role of officialdom in the birth of a 'xenophobian nationalism' by the reign of Edward III (at 407). 
${ }^{37}$ W. M. Ormrod, 'Accountability and collegiality: the English royal secretariat in the mid-fourteenth century’, in Fianu \& Guth, Écrit, pp. 55-85, esp. pp. 76-84; Malcolm Richardson, The medieval chancery under Henry V, List and Index Society, Special Series, vol. XXX (Kew, 1999), pp. 34-5. ${ }^{38}$ See estimates in Michael Prestwich, Plantagenet England, 1225-1360 (Oxford: Oxford UP, 2005), p. 55; Brown, Governance, p. 52; see also figures cited by Scales, above, p. ++. The best guide to the nature of these sources remains Pierre Chaplais, English royal documents, King John-Henry VI, 1199-1461 (Oxford: Clarendon Press, 1971).

${ }^{39}$ R. F. Hunnisett, 'English chancery letters: rolls and files', Journal of the Society of Archivists 5:3 (1975), 158-68, esp. 163, 167-8.

${ }^{40}$ M. S. Giuseppi, A guide to the manuscripts preserved in the Public Record Office (London, 1923), vol. I, pp. 17-42; List of chancery rolls preserved in the Public Record Office (Public Record Office Lists and Indexes, no. 27: Dublin, 1908).

${ }^{41}$ Thomas Hoccleve, Regiment of Princes, lines 1013-15 ('But we laboure in travaillous stilnesse; | We stowpe and stare upon the sheepes skyn, | And keep moot our song and wordes yn'). For discussion, see Ethan Knapp, The bureaucratic muse: Thomas Hoccleve and the literature of late medieval England (University Park PA: Pennsylvania State UP, 2001); T. F. Tout, 'The human side of mediaeval records', TRHS 11 (1928), 1-16, esp. 2-3.

${ }^{42}$ Jean-Philippe Genet, L'état moderne, genèse: bilans et perspectives (Paris, 1990), p. 306.

${ }^{43}$ The most sophisticated account presents the shift as one from a 'domain state' to a 'tax state' by the fourteenth century: W. M. Ormrod, 'England in the Middle Ages', in Richard Bonney, The rise of the fiscal state in Europe, c.1200-1815 (Oxford: Oxford UP, 1999).

${ }^{44}$ Admin. Ire.

${ }^{45}$ Pierre Chaplais, 'The making of the treaty of Paris (1259) and the royal style', in Chaplais, Essays in medieval diplomacy and administration (London: Hambledon, 1981), ch. 1.

${ }^{46}$ John Le Patourel, The medieval administration of the Channel Islands, 1199-1399 (Oxford: Oxford UP, 1937), pp. 6-7. For a later period, see Tim Thornton, The Channel Islands, 1370-1460: between England and Normandy (Woodbridge: Boydell Press, 2012). 
${ }^{47}$ L. terra Vasconie non erat nec esse recognoscebatur de feodo regis Francie, set de allodio regis Anglie: C 47/29/4, no. 9, TNA; printed in Pierre Chaplais, English medieval diplomatic practice, part I: documents and interpretation, 2 vols. (London: HMSO, 1982), vol. I, p. 422.

${ }^{48}$ Pierre Chaplais, 'English arguments concerning the feudal status of Aquitaine in the fourteenth century', BIHR 21:64 (1948), 203-13; Malcolm Vale, The origins of the Hundred Years War: the Angevin legacy, 1250-1340, 2nd edn (Oxford: Clarendon Press, 1996), esp. pp. 59-63; and, for a later period, Malcolm Vale, English Gascony, 1399-1453 (Oxford: Oxford UP, 1970), esp. ch. 1.

${ }^{49}$ R. R. Davies, ‘Colonial Wales’, P\&P 65 (1974), 3-23 (quotation at 14).

${ }^{50}$ Ralph A. Griffiths. The principality of Wales in the later Middle Ages: the structure and personnel of government (Cardiff: University of Wales Press, 1972), pp. 1-17, pp. 35-6.

${ }^{51}$ R. R. Davies, The age of conquest: Wales, 1063-1415, 2nd edn (Oxford: Oxford UP, 2000), pp. $333-54$.

${ }^{52} \mathrm{~W} . \mathrm{H}$. Waters. The Edwardian settlement of north wales in its administrative and legal aspects (1284-1343) (Cardiff: University of Wales Press Board, 1935), pp. 7-30. The eastern portion of Gwynedd ('Is Conwy') was carved into a series of Marcher lordships (James Given, State and society in medieval Europe: Gwynedd and Languedoc under outside rule (Ithaca: Cornell UP, 1990), p. 44). ${ }^{53}$ Llinos Beverley Smith, 'The statute of Wales, 1284', WHR 10:2 (1980), 127-54. James Given slightly overstates the case when he remarks that: 'What the statute envisaged, and what the English accomplished over the next few years, was the near total importation of an English-style government' (Given, State and society, pp. 44-6).

${ }^{54}$ Fiona Watson, Under the hammer: Edward I and Scotland, 1286-1307 (East Linton: Tuckwell, 1998), esp. ch. 2.

${ }^{55}$ Joseph Stevenson (ed.), Documents illustrative of the history of Scotland [...] (Edinburgh, 1870), vol. II, pp. 163-4.

${ }^{56}$ See Jonathan Gledhill, 'Locality and allegiance: English Lothian, 1296-1318', in Andy King and David Simpkin (eds.), England and Scotland at war, c.1296-c.1413 (Leiden: Brill, 2012), 157-82. 
${ }^{57}$ The 'lands beyond the Tweed' included the whole of Lothian together with the sheriffdoms of Dumfries, Kirkcudbright, Roxburgh, Selkirk, Peebles, Berwick and Edinburgh (with the constabularies of Haddington and Linlithgow): see Ranald Nicholson, Edward III and the Scots: the formative years of a military career, 1327 to 1333 (Oxford: Oxford UP, 1965), pp. 158-62; Bruce Webster, 'The English occupations of Dumfriesshire in the fourteenth century', Transactions of the Dumfriesshire and Galloway Natural History and Antiquarian Society 35 (1957), 64-80; Iain A. MacInnes, “ “To be annexed forever to the English crown”: the English occupation of southern Scotland, c.1334-1337', in King and Simpkin (eds.), England and Scotland at war, pp. 183-201. ${ }^{58}$ Anthony Tuck, 'A medieval tax haven: Berwick upon Tweed and the English crown, 1333-1461', in John Hatcher and R. H. Britnell (eds.), Progress and problems in medieval England: essays in honour of Edward Miller (Cambridge: Cambridge UP, 1996), pp. 148-67

${ }^{59}$ W. M. Ormrod, ‘England: Edward II and Edward III’, in Michael Jones (ed.), NCMH, vol. vI: c.1300-c.1415 (Cambridge: Cambridge UP, 2000), p. 279.

${ }^{60}$ The years of English administration were: 1279-94, 1299-1318, 1320-4, 1327-37, 1361-69. See Emmitt Howard Shealy Jr, ‘The English administration of Ponthieu, 1229-1369’ (Ph.D., Emory University, 1977), ch. 2.

${ }^{61}$ David Grummitt, “ "One of the mooste pryncipall treasours belongyng to his realme of Englande”: Calais and the crown, c.1450-1558', in David Grummitt (ed.), The English experience in France, c.1450-1558: war, diplomacy and cultural exchange (Aldershot: Ashgate, 2002), pp. 46-62. See also Le Patourel, 'L’occupation anglaise de Calais', in Le Patourel, Feudal empires, ch. 14; and R. L. Baker, 'The government of Calais in 1363' in William C. Jordan (ed.), Order and innovation in the Middle Ages: essays in honour of Joseph R. Strayer (Princeton: Princeton UP, 1976), pp. 208-11. ${ }^{62}$ C. T. Allmand, Lancastrian Normandy, 1415-1450: the history of a medieval occupation (Oxford: Clarendon Press, 1983).

${ }^{63}$ R. A. Newhall, The English conquest of Normandy, 1416-1424: a study in fifteenth century warfare (New Haven: Yale UP, 1924), ch. 3; Anne Curry, 'Henry V’s conquest of Normandy, 1417-19: the 
siege of Rouen in context', XXXI Semana de Estudios Medievales Estella, 19-23 de Julio 2004 (2005), 237-54.

${ }^{64}$ Anne Curry, 'Two kingdoms, one king: the Treaty of Troyes (1420) and the creation of a double monarchy of England and France', in Glenn Richardson (ed.), 'The contending kingdoms': France and England 1430-1700 (Aldershot: Ashgate, 2008), pp. 24-41.

${ }^{65}$ These movements are traced in Anne Curry, 'L'administration financière de la Normandie anglaise: continuité ou changement?’, in P. Contamine and O. Mattéoni (eds.), La France des principautés: les chambres des comptes $X I V^{e}$ et $X V^{e}$ siècles (Comité pour l'histoire économique et financière de la France: Paris, 1996), pp. 83-103; Curry, 'La chambre des comptes de Normandie sous l’occupation anglaise, 1417-1450', in P. Contamine and O. Mattéoni (eds.), Les chambres des comptes en France aux XIV $V^{e}$ et $X V^{e}$ siècles (Comité pour l’histoire économique et financière de la France: Paris, 1998), pp. $91-125$.

${ }^{66}$ Guy Llewelyn Thompson, Paris and its people under English rule: the Anglo-Burgundian regime, 1420-1436 (Oxford: Oxford UP, 1991), ch. 1.

${ }^{67}$ Anne Curry, ‘The loss of Lancastrian Normandy: an administrative nightmare?', in David Grummitt (ed.), The English experience in France, c.1450-1558: war, diplomacy and cultural exchange (Aldershot: Ashgate, 2000), esp. pp. 24-45.

${ }^{68}$ L. ad dictum regnum spectantibus officiales nostros et ministros ad regimen ejusdem regni Scocie prefecimus jure nostro (E. L. G. Stones, Anglo-Scottish relations, 1174-1328: some selected documents, 2nd edn (Oxford: Clarendon Press, 1970), no. 30, at pp. 216-17). Edward I's assertion was in confutation of the papal bull Scimus fili (27 June 1299), which refers to Edward's actions in establishing 'royal officials in the same realm [Scotland], who fear not to perturb the prelates and other clergy and the ecclesiastical and secular persons of the realm with manifold vexations ... [to] the injury of the royal welfare and reputation, the outrage of justice, and the grave scandal of many of the faithful', and instructs him to recall his officials from Scotland without delay (ibid., no. 28, at pp. 172-3). Cf. Edward III's claim to have 'undertaken the government' of the kingdom of France in his manifesto issued in 1340 upon assuming the title king of France (Foedera, vol. II, pp. 1108-9). 
${ }^{69}$ For structural similarities, see Ruddick, 'Gascony and the limits', in Smith (ed.), Ireland and the English world in the Middle Ages, p. 72; and for a direct comparison between Ireland and Aquitaine, see Green, ‘Lordship and principality’.

${ }^{70}$ Kenneth Fowler, 'Les lieutenants du roi d'Angleterre'.

${ }^{71}$ J.-P. Trabut-Cussac, L'administration anglaise en Gascogne sous Henry III et Edouard I de 1254 à 1307 (Société de l’École des Chartes, Mémoires et Documents 20: Geneva, 1972), pp. 175-91, 194211. The seal was engraved 'sigillum curie Vasconie' until c.1390, when the legend was changed to read 'sigillum officii senescallie Aquitannie', which more accurately described its function as a seal of office: see Pierre Chaplais, ‘Le sceau de la cour de Gascogne ou sceau de l’office de sénéchal de Guyenne’, in Chaplais, Essays, ch. 9, pp. 19-29; Pierre Chaplais, 'The chancery of Guyenne’, in Chaplais, Essays, ch. 9, pp. 76-7, 84.

${ }^{72}$ Sheila Bredon Storey-Challenger, L'administration anglaise du Ponthieu après le traité de Brétigny, 1361-1369 (Abbeville: Société d'émulation historique et littéraire d'Abbeville, 1975), pp. $33-44$.

${ }^{73}$ In 1279 Edward I sent a seal to be used in the Channel Islands; but, from the early fourteenth century, the two seals in use were not 'royal' seals, sensu stricto, but rather seals of the office of bailli bearing the legend 'sigillum ballivie' (Julien Havet, Les cours royales des îles normandes (Paris, 1878), pp. 159-64).

${ }^{74}$ On the Irish chancery, see A. J. Otway-Ruthven, 'The medieval Irish chancery', Album Helen Maud Cam [...], 2 vols. (Paris and Louvain, 1961), vol. II, pp. 119-38, repr. in Peter Crooks (ed.), Government, war and society in medieval Ireland: essays by Edmund Curtis, A. J. OtwayRuthven and James Lydon (Dublin: Four Courts, 2008), ch. 3; Admin. Ire., pp. 14-21.

${ }^{75}$ There was no chancellor or chancery in the principality of Wales: the chamberlains of the north and south had the keeping of the king's seal of the principality and served the secretarial functions performed elsewhere by chanceries and their staff (Waters, Edwardian settlement, p. 24; Griffiths, Principality, pp. 37-8). The offices of chamberlain and the chancellor of Berwick were very often invested in the same person, although separate patents of appointments were issued for each office 
(Beryl L. Atkinson, ‘Berwick upon Tweed in the wars of Edward III’ (MA, University of Leeds, 1959), p. 140-1).

${ }^{76}$ Though the reverse side of the deputed seals shows the royal arms rather than an equestrian portrait of the monarch. For analysis of the deputed seals, see Hilary Jenkinson, 'The great seal of England: deputed or departmental seals’, Archaeologia 85 (1936), 293-338; Griffiths, Principality, pp. 3-8, 37; Hilary Jenkinson, 'A seal of Edward II for Scottish affairs’, The Antiquaries Journal 11 (July 1931), 229-39 at p. 229 (king's seal 'deputed for the governance of the realm of Scotland' [L. ad regimen regni Scocie deputatum]); C. H. Hunter-Blair, 'The mediaeval seals of Berwick-upon-Tweed', p. 406 (king’s seal 'for his land beyond the Tweed’ [L. pro terra sua ultra Twedam]).

${ }^{77}$ Peter Walne, ‘The royal seals of colonial America’, Antiques 114 (1978), 142-9.

${ }^{78}$ CCR 1272-9, p. 361.

${ }^{79}$ CCR 1339-41, p. 259. The fact that the king had to articulate the point is a reminder that there were large areas, such as the Welsh march and the greater liberties of England, where the king's writ was not current. The crown sought to develop the argument that the lords of even the greatest liberties (such as the palatinate of Durham) were his ministers. See the recent overview by Keith Stringer, 'States, liberties and communities in medieval Britain and Ireland (c.1100-1400)', in Michael Prestwich (ed.), Liberties and identities in the medieval British Isles (Woodbridge: Boydell, 2008), ch. 1. The significance of the greater palatinates for later imperial history lies in the fact that their liberties provided the model for the proprietary colonies of early English America: see Tim Thornton, 'The palatinate of Durham and the Maryland charter', American Journal of Legal History 45:3 (2001), 235-55. pp. 14-15.

${ }^{80}$ Andy King (ed.), Sir Thomas Gray, Scalacronica, 1272-1363 (Woodbridge: Boydell Press, 2005), pp. 38-9. On the lieutenant in question, see Andrew M. Spencer, 'John de Warenne, guardian of Scotland, and the battle of Stirling Bridge', in King and Simpkin (eds.), England and Scotland at war, pp. 39-51.

${ }^{81}$ List of chancery rolls, pp. 59-61, 65-6. A number of other miscellaneous rolls dating from Edward III's absences on campaign in France, for instance the so-called 'Brittany', 'Calais', and 'Normandy' 
rolls, have been printed in calendar form as part of the series of English patent rolls (W. M. Ormrod, 'A problem of precedence: Edward III, the double monarchy, and the royal style', in James S. Bothwell (ed.), The age of Edward III (York, 2001), p. 139 n. 24).

${ }^{82}$ C 61, TNA. For an edition of the Gascon rolls of Edward II, see Yves Renouard (ed.), Gascon rolls, 1307-17 (Paris, 1966). The complete series of Gascon rolls (which also contain some entries for Ponthieu) are currently being calendared for publication (www.gasconrolls.org, accessed 18 June 2014).

${ }^{83}$ C 77, TNA. See Calendar of various Chancery Rolls: supplementary close rolls, Welsh rolls, scutage rolls, 1277-1326 (London, 1912), pp. 157-361.

${ }^{84}$ C 71, TNA; Rotuli Scotiae_in turri Londinensi et in domo capitulari Westmonasteriensi asservati, ed. D. Macpherson et al., 2 vols. (London, 1814), quotation at vol. I, p. 1.

${ }^{85}$ C 64, TNA. The earlier rolls, which begin in Aug. 1417, are printed in Rot. norm. For a calendar of the later rolls (which continue until Henry V's death and the start of the 'double monarchy' of Henry VI changed the constitutional situation), see the 'Calendar of the Norman rolls', DKR 41 (1880), 678810; DKR 42 (1881), 313-473.

${ }^{86}$ The 'Irish rolls' referred to in List of chancery rolls, p. xi, are actually memoranda concerning affairs in Ireland that were transmitted to the administration at Westminster. Some of these memoranda are printed in J. Ayloffe (ed.), Calendar of the ancient charters [...] (1772), 444-62. ${ }^{87}$ A task that can now only be accomplished patchily because the surviving archives of these administrations suffered serious losses, even in the Middle Ages. For the fate of the archives of Gascony captured by the French when they took the island of Oléron in 1294, see G. P. Cuttino, 'The archives of Gascony under English rule’, American Archivist 25:3 (1962), 315-21. There are no extant examples of the rolls kept by the chancellor of Berwick to record documents issued under the seal of the lands beyond the Tweed (Atkinson, 'Berwick upon Tweed', p. 23). The archival history of the Irish chancery is described in Peter Crooks, 'Reconstructing the past: the case of the Irish chancery rolls', in Felix M. Larkin and N. M. Dawson (eds.), Lawyers, the law and history: Irish Legal History Society discourses and other papers, 2006-2011 (Dublin: Four Courts, 2013), 281-309. 
For a reconstruction of the Irish chancery rolls, which were destroyed in 1922, see www.tcd.ie/chancery, accessed 18 June 2014.

${ }^{88}$ Contrast the 'parchment imperialists’ of the medieval German Reich: see Scales, above, pp. ${ }^{++}$.

${ }^{89}$ Pierre Chaplais, English diplomatic practice in the Middle Ages (London: Hambledon, 2003), p. 107; EHD, vol. IV, no. 19, quotation at p. 66.

${ }^{90}$ Michael Prestwich, ‘England and Scotland during the wars of independence’, in Michael Jones and M. G. A. Vale (eds.), England and her neighbours, 1066-1453: essays in honour of Pierre Chaplais (London: Hambledon, 1989), pp. 181-216.

${ }^{91}$ Edouard Perroy (ed.), The diplomatic correspondence of Richard II, CS, 3rd series, XLVIII (London, 1933), no. 34.

${ }^{92}$ Robin Frame, 'English officials and Irish chiefs in the fourteenth century’, EHR 90:357 (1975), 748-77, esp. 751, 775 (repr. in Frame, Ireland and Britain); Katharine Simms, From kings to warlords: the changing political structures of Gaelic Ireland in the later Middle Ages (Woodbridge: Boydell, 1987), pp. 34-40.

${ }^{93}$ Edmund Curtis (ed.), Richard II in Ireland, 1394-5, and submissions of the Irish chiefs (Oxford: Clarendon Press, 1927), instrument VII (text p. 68, trans. p. 158); letter 10 (text p. 131, trans. p. 211). ${ }^{94}$ H. Rothwell (ed.), The chronicle of Walter of Guisborough, CS, 3rd series, LXXXIX (1957), p. 251; a writ of 17 July 1306 refers to the 'rolls of the exchequer [which] were burnt in the said castle of Carnervan [sic] during the war in Wales' (CCR 1302-7, p. 397). See John Griffiths, 'The revolt of Madog ap Llywelyn, 1294-5’, Caernarvonshire Historical Society Transactions 16 (1955), 14. The Welsh burned the records at Conwy during the revolt of Owain Glyn Dŵr (M. M. N. Stansfield, 'Prosopography and the Principality of Wales, 1284-1536: the second stage', Medieval Prosopography 12:2 (1991), 1-33, at 17). In Ireland, An Calbhach Ó Conchobair Failge (a leader of the O Connors of Offaly) captured the castle of Kildare in 1294 and 'burned the rolls and tallies of the county’ (J. T. Gilbert (ed.), Chartularies of St. Mary’s Abbey, Dublin [...], 2 vols. (London: RS, 1884), vol. II, p. 323).

${ }^{95}$ Stones, Anglo-Scottish relations, pp. 152-3. 
${ }^{96}$ Gesta Henrici Quinti, p. 55 n. 44; Anne Curry, 'The impact of war and occupation on urban life in Normandy, 1417-1450’, French History 1:2 (1987), 159.

${ }^{97}$ As Sir Francis Palgrave (1788-1861) referred to the Public Record Office founded at Chancery Lane in 1838 (Aidan Lawes, Chancery Lane, 1377-1977: 'The strong box of the empire' (Kew: PRO Publications, 1996), p. 19).

${ }^{98}$ See Jean-Philippe Genet, La genèse de l'état moderne: culture et société politique en Angleterre (Paris, 2003), p. 115, for the creation of a 'mémore écrite'. On Hardyng, see Alfred Hiatt, The making of medieval forgeries: false documents in fifteenth-century England (London: BL and University of Toronto Press, 2004), pp. 106-7. Hardyng’s forgeries are listed in E. L. G. Stones and Grant G. Simpson (eds.), Edward I and the throne of Scotland, 1290-1296: an edition of the record sources for the Great Cause (Oxford: Oxford UP, 1978), vol. II, pp. 385-6.

${ }^{99}$ Nicholas Vincent, ‘The great lost library of England’s kings: royal use and ownership of books, 1066-1272', Kathleen Doyle and Scot McKendrick (eds.), 1000 Years of royal books and manuscripts (Chicago: University of Chicago Press, 2014), p. 82.

${ }^{100}$ Stones, Anglo-Scottish relations, pp. 192-3.

${ }^{101}$ Stones and Simpson (eds.), Edward I and the throne of Scotland, esp. vol. I, appendix 3, pp. 20910.

${ }^{102}$ For the information-gathering exercises of Edward I in Gascony (1273-4), the Channel Islands (1274), and Wales (1280), see esp. Sandra Raban, 'Edward I’s other inquiries’, in Michael Prestwich, R. H. Britnell and Robin Frame (eds.), Thirteenth century England IX: proceedings of the Durham conference, 2001 (Woodbridge: Boydell, 2003), 43-57. ${ }^{103}$ CCR 1318-23, p. 319. Discussion in G. P. Cuttino, English diplomatic administration, 1259-1339 (London: Oxford UP, 1940), p. 78; V. H. Galbraith, 'The tower as an exchequer record office in the reign of Edward II', in A. G. Little and F. M. Powicke (eds.), Essays in medieval history presented to Thomas Frederick Tout (Manchester: Manchester UP, 1925), pp. 231-47, esp. 234-5, 244.

${ }^{104}$ G. P. Cuttino, English diplomatic administration, 1259-1339 (London: Oxford UP, 1940); Stones and Simpson (eds.), Edward I and the throne of Scotland, vol. I, p. 36. 
${ }^{105}$ The distinction is a fuzzy one: the problem of Scotland within English diplomacy is considered in J.-P. Genet, 'Scotland in the later Middle Ages: a province or a foreign kingdom for the English?', in Hannah Skoda and Robert Shaw (eds.), Contact and exchange in later medieval Europe: essays in honour of Malcolm Vale (Woodbridge: Boydell, 2012), ch. 8.

${ }^{106}$ E 36/274-5, TNA (compiled between c. 1282 and c.1305). The Welsh section of Liber A is printed in J. Goronwy Edwards (ed.), Littere Wallie preserved in Liber A in the Public Record Office (Cardiff: UP Board, 1940). For the missing Scottish section of Liber A, see below, n. 114. ${ }^{107}$ Gascon register A (series of 1318-1319), ed. by G. P. Cuttino with the collaboration of J.-P. Trabut-Cussac, 3 vols. (Oxford: Oxford UP, 1975); G. P. Cuttino (ed.), The Gascon calendar of 1322, CS 3rd series, LXX (London: RHS, 1949). Later in the century, inquisitions concerning the laws of Calais were copied on to the 'French rolls' of the kings of England (Le Patourel, 'L'administration anglaise de Calais', in Le Patourel, Feudal empires, ch. 14, at p. 233).

${ }^{108}$ CPR 1321-4, p. 7; Mark Buck, Politics, finance and the church in the reign of Edward II: Walter Stapeldon, treasurer of England (Cambridge: Cambridge UP, 1983), pp. 167-8.

${ }^{109}$ F. C. Palgrave (ed.), The antient kalendars and inventories of the treasury of His Majesty's Exchequer, 3 vols. (London, 1846).

${ }^{110}$ Palgrave (ed.), Antient kalendars, vol. I, esp. pp. 116, 118, 122. Similar signa also appear in Liber A, the Welsh signa being reproduced in facsimile in Edwards (ed.), Littere Wallie, frontispiece and facing p. 139. The Irish signa (Figs. 11.5-6, reproduced from E 36/274, fos. 38r and 435r, TNA) are discussed in H. F. McClintock, Old Irish and highland dress (Dundalk: Dundalgan Press, 1950), pp. $23-5$.

${ }^{111}$ For the wider context of 'ethnographic illustration' in the Middle Ages, see Robert Bartlett, 'Illustrating ethnicity in the Middle Ages', in Mirian Eliav-Feldon, Benjamin Isaac and Joseph Ziegler (eds.), The origins of racism in the West (Cambridge: Cambridge UP, 2009), ch. 6.

${ }^{112}$ Seymour Phillips, Edward II (New Haven and London: Yale UP, 2010), p. 445.

${ }^{113}$ Stones and Simpson (eds.), Edward I and the throne of Scotland, vol. I, pp. 45-7, 81-2; vol. II, pp. 378-80. 
${ }^{114}$ As a result the Scottish section of Liber A is now missing, but a list of its contents survives and is printed in Stones and Simpson (eds.), Edward I and the throne of Scotland, vol. I, appendix IV (pp. 211-12). See also E. L. G. Stones, 'The appeal to history in Anglo-Scottish relations between 1291 and 1401, part II', Archives 9 (1969).

${ }^{115}$ Gesta Henrici Quinti, pp. 138-9 (L. petitis pro parte Regis per legitima documenta que intitulantur in codice recordorum).

${ }^{116}$ Curtis (ed.), Richard II in Ireland, prints the submissions taken from the memoranda roll: E 159/171, TNA. The original deeds survive as C 47/10/25, TNA.

${ }^{117}$ Henry F. Berry (ed.), Statutes and ordinances, and acts of the parliament of Ireland, King John to Henry V (Dublin: HMSO, 1907), pp. 564-5; Elizabeth Matthew, 'Henry V and the proposal for an Irish crusade', in Smith (ed.), Ireland and the English world, ch. 11.

${ }^{118}$ The anecdote occurs in the apothegms of Sir Francis Bacon (d. 1626): The works of Francis Bacon, [...] lord chancellor of England, ed. J. Spenning, R. L. Ellis and D. D. Heath, 14 vols. (London: Longmans, 1861-1879), vol. VII, p. 130-1.

${ }^{119}$ David Harvey, 'Space as a keyword', in Harvey, Spaces of global capitalism (London: Verso, 2006), ch. 3. For an application of Harvey’s ideas to imperial history, see Alan Lester, 'Relational space and life geographies in imperial history: George Arthur and humanitarian governance', Journal of the Canadian Historical Association 21:2 (2010), 29-46.

${ }^{120}$ Admin. Ire., p. 58. On royal control of office-holders more generally, see Frédérique Lachaud, L'éthique du pouvoir au moyen âge: l'office dans la culture politique (Angleterre, vers 1150-1330) (Paris: Éditions classiques Garnie, 2010), pp. 544-56.

${ }^{121}$ For the financial offices in English France between 1416 and 1449, see above, n. 65; and Neil Murphy, 'War, government and commerce: the towns of Lancastrian France under Henry V's rule, 1417-22’, in Gwilym Dodd (ed.), Henry V: new interpretations (Woodbridge: York Medieval Press, 2013), ch. 10.

${ }^{122}$ Mary C. Hill, The king's messengers, 1199-1377: a contribution to the history of the royal household (London: Edward Arnold, 1961), p. 107. 
${ }^{123}$ James F. Willard, 'The dating and delivery of letters patent and writs in the fourteenth century', BIHR 10:28 (1932), 1-11: 'When there was need of haste the chancery and exchequer could act quickly' (at 11).

${ }^{124}$ The return crossing from the Americas to Spain was considerably longer than the outward voyage: for a table showing voyage times from Andalusia to the Indies, see Mark A. Burkholder and Lyman L. Johnson, Colonial Latin America, 7th edn (Oxford: Oxford UP, 2010), p. 95. See also J. H. Elliott, 'King and patria in the Hispanic world', in Elliott, SEWW, p. 174; Storrs, below, p. ++. ${ }^{125}$ Dorothy M. Broome, 'Exchequer migrations to York in the thirteenth and fourteenth centuries', in A. G. Little and F. M. Powicke (eds.), Essays in medieval history presented to Thomas Frederick Tout (Manchester: Manchester UP, 1925), pp. 295-7.

${ }^{126}$ C. A. J. Armstrong, 'Some examples of the distribution and speed of news in England at the time of the Wars of the Roses', England, France and Burgundy in the fifteenth century (London:

Hambledon, 1983), pp. 107, 113. For other examples of a postal system on the roads from London to Scotland and Wales, see J. R. Alban and C. T. Allmand, 'Spies and spying in the fourteenth century', in C. T. Allmand (ed.), War, literature and politics in the late Middle Ages (Liverpool, 1976), pp. 73101 , at $85-6$.

${ }^{127}$ Aubrey Gwynn, 'The black death in Ireland', Studies 23:93 (1935), 34.

${ }^{128}$ Frame, English lordship, pp. 114-19, esp. Table 9. For the voyage time to Bordeaux, see Yves Renouard, ‘Ce que l'Angleterre doit à l'Aquitaine’, in Charles-Edmond Perrin (ed.), Études d'histoire mediévale (Paris: SEVPN, 1968), p. 872).

${ }^{129}$ A digitized and searchable version of the map is accessible online at www.goughmap.org, accessed 18 June 2014. For discussion of the roads, see Brian Paul Hindle, 'The road network of medieval England and Wales’, Journal of Historical Geography 2:3 (1976), 207-21.

${ }^{130}$ Keith D. Lilley, Christopher D. Lloyd and Bruce M. S. Campbell, 'Mapping the realm: a new look at the Gough map of Britain (c.1360)', Imago Mundi 61:1 (2010), 2. See also Daniel Birkholz, The king's two maps: cartography and culture in thirteenth-century England (London and New York: Routledge, 2004), who places the map in the reign of Edward I. 
${ }^{131}$ Keith D. Lilley, 'Mapping Plantagenet rule through the Gough map of Great Britain’, in Ingrid Baumgärtner and Martina Stercken (eds.), Herrschaft verorten: politische Kartographie des Mittelalters und der frühen Neuzeit (Chronos, 2012), pp. 77-97.

${ }^{132}$ Lilley et al., 'Mapping the realm', 2.

${ }^{133}$ Philomena Connolly, “ "The head and comfort of Leinster”: Carlow as the administrative capital of Ireland, 1361-1394', in Thomas McGrath (ed.), Carlow: history and society (Dublin: Geography Publications, 2008), ch. 12.

${ }^{134}$ James Graves (ed.), A roll of the proceedings of the king's council in Ireland [...], 1392-93

(London: Rolls Series, 1877), pp. 11-12.

${ }^{135}$ Smith (ed.), Ireland and the English world. Cf. Miles Ogborn, Global lives: Britain and the world, 1550-1800 (Cambridge: Cambridge UP, 2008).

${ }^{136}$ Paul Brand (ed.), 'Parliament of Edward I, roll 6, Item 23', in PROME, accessed 18 June 2014).

${ }^{137}$ The procedure is outlined in Admin. Ire., pp. 57-64. For Gascony, see E. C. Lodge, 'The constables of Bordeaux in the reign of Edward III', EHR 50:198 (1935), 225-41.

${ }^{138}$ See Crooks, 'State of the union', 23-6; Green, 'Lordship and principality’, 27 n. 118 (on 'colonial staff'); Frame, 'Rediscovering medieval Ireland', 11-12.

${ }^{139}$ Griffiths, Principality, p. 317-18. The financial officers in Wales, Berwick, Calais (from 1360) and Harfleur (1417-19) also presented accounts at the Westminster exchequer.

${ }^{140}$ CCR 1324-7, p. 77.

${ }^{141}$ Atkinson, 'Berwick upon Tweed in the wars of Edward III', p. 126; Frame, English lordship, p. 92 and n. 47. In addition, Power also held office in Ireland as escheator and justice of the common bench (Admin. Ire., pp. 101, 108, 127, 158; Griffiths, Principality, pp. 317-18).

${ }^{142}$ T. Runyan, 'The constabulary of Bordeaux: the accounts of John Ludham (1372-73) and Robert de Wykford (1373-5)', Mediaeval Studies, 36 (1974), esp. 224-6.

${ }^{143}$ Chaplais, 'Le sceau de la cour de Gascogne’, in Chaplais, Essays, ch. 9, p. 25. 
${ }^{144}$ J. S. Roskell, 'William Allington of Horseheath’, Parliament and politics in late medieval England, vol. III (London: Hambledon, 1981), pp. 317-29; W. M. Palmer (ed.), Monumental inscriptions and coats of arms from Cambridgeshire (1932), p. 85.

${ }^{145}$ Titi Livii Foro-Juliensis,Vita Henrici Quinti, regis Angliae, ed. Thomas Hearne (Oxford, 1716), p. 33.

${ }^{146}$ David Rundle, ‘The unoriginality of Tito Livio Frulovisi’s Vita Henrici Quinti’, EHR 123:504 (2008), 1128 (quotation).

${ }^{147}$ Carpenter, 'War, government and governance', in Clark (ed.), Fifteenth Century VII, p. 22. ${ }^{148}$ Contrast Prestwich, Plantagenet England, p. 77 ('the greatest test that was faced was that of organizing war').

${ }^{149}$ A point noted by Anne Curry in her study of Normandy under English occupation in the second quarter of the fifteenth century: Anne Curry, 'Pour ou contre le roi d'angleterre? La discipline militaire et la contestation du pouvoir en Normandie au XV'e siècle', in Catherine Bougy and Sophie Poirey (eds.), Images de la contestation du pouvoir dans le monde normand: $X^{e}-X V I I I{ }^{e}$ siècle: actes $d u$ colloque de Cerisy-la-Salle, 29 septembre-3 octobre 2004 (Caen: Université de Caen-Basse Normandie, 2007), pp. 147-62.

${ }^{150}$ R. R. Davies, 'The English state and the Celtic peoples', in Wong \& Sayer, British state, p. 160. Susan Reynolds uses similar weberian terminology in her study of lay collective solidarities in Europe between 900 and 1300 to describe 'a change from traditional and patrimonial government to bureaucratic government, with attitudes towards it—reasonably enough—lagging behind' (Reynolds, Kingdoms and communities in Western Europe, 900-1300, 1st edn (Oxford: Clarendon Press: Oxford, 1984), p. 334).

${ }^{151}$ Davies, Domination, p. 120.

${ }^{152}$ Davies, Domination, p. 121.

${ }^{153}$ Davies, Empire, p. 201; Davies, 'The failure of the first British empire? England's relations with Ireland, Scotland and Wales, 1066-1500', in Nigel Saul (ed.), England in Europe, 1066-1453 (London, 1994), p. 131. 
${ }^{154}$ Davies, Empire, ch. 7.

${ }^{155}$ Davies, 'English state’, in Wong \& Sayer, British state, p. 165 (quotation); and see also R. R.

Davies, 'The medieval state: the tyranny of a concept?', in Wong and Sayer, British state, pp. 294314.

${ }^{156}$ T. F. Tout, The place of Edward II in English history: based upon the Ford lectures delivered in the University of Oxford in 1913 (Manchester: Manchester UP), pp. 34, 206.

${ }^{157}$ For the distinction, see Reynolds, 'Empire’, 152; Burbank \& Cooper, Empires, p. 8; introduction, above, pp. ${ }^{++}$.

${ }^{158}$ Davies, Domination, p. 126 (quotation); and see also Davies' comments on the 'integrationist and uniformist' language of the 'unitary state' ('English state', in Wong and Sayer, British state, esp. p. 165).

${ }^{159}$ For this phrase, see Barkey, above, p. ++; Barkey, Empire of difference.

${ }^{160}$ Davies, 'English state’, in Wong and Sayer, British state, p. 169.

${ }^{161}$ G. L. Harriss, 'Political society and the growth of government in late medieval England', $P \& P 138$ (1993), 28-57; Chris Given-Wilson, 'The problem of labour in the context of English government, c.1350-1450', in James Bothwell, P. J. P. Goldberg and W. M. Ormrod (eds.), The problem of labour in fourteenth-century England, ed. (Woodbridge: York Medieval Press, 2000), pp. 85-100.

${ }^{162}$ M. Dominica Legge, Anglo-Norman Letters and Petitions from All Souls MS 182 (Oxford: Basil Blackwell, 1941), no. 230. Compare the first letter of Joan of Arc to the English (dated c.22 March 1429) in which she calls on John duke of Bedford, 'who call[s] himself regent of France', to leave the kingdom of France, together with his commanders, threatening that any Englishmen who remained in France would be killed (Craig Taylor (ed.), Joan of Arc: La Pucelle (Manchester: Manchester UP, 2006), no. 4, pp. 74-5).

${ }^{163}$ Janet Coleman, 'A political analysis of literary works, c.1280-1400: ideology and the perception of "the state” in England', in J.-P. Genet (ed.), Culture et idéologie dans la genèse de l'état moderne (Rome: École française de Rome, 1985), pp. 433-62. 
${ }^{164}$ G. W. S. Barrow, Robert Bruce and the community of the realm of Scotland, 1st edn (1965), p. 110. Watson, Under the hammer, p. 55, notes that the very effectiveness of Cressingham made him unpopular.

${ }^{165}$ Chronicle of Walter of Guisborough, ed. Rothwell, p. 303; Henry Summerson, 'Cressingham, Hugh of (d. 1297), administrator and justice', ODNB.

${ }^{166}$ Stones, Anglo-Scottish relations, no. 33, esp. pp. 122-3.

${ }^{167}$ See Prestwich, Plantagenet England, pp. 236-9, which takes a more sceptical view of Edward I’s success in fostering 'consensus and acquiescence' in the ordinance of 1305 than Watson, Under the hammer, p. 220. For Edward I’s brutalities after 1306, see Matthew Strickland, 'Treason, feud and the growth of state violence: Edward I and the "war of the earl of Carrick”, 1306-7', in Chris GivenWilson, Ann Kettle and Len Scales (eds.), War, government and society in the British Isles, c.1150 1500 (Woodbridge: Boydell, 2008), pp. 84-113.

${ }^{168}$ Shealy, ‘The English administration of Ponthieu, 1229-1369’ (Ph.D.), pp. 59-60; E. Howard Shealy, 'The persistence of particularism: the county of Ponthieu in the thirteenth and fourteenth centuries’, in J. S. Hamilton and Patricia J. Bradley (eds.), Documenting the past: essays in medieval history presented to George Petty Cuttino (Woodbridge: Boydell, 1989), pp. 35-6.

${ }^{169}$ Vale, Origins of the Hundred Years War, pp. 73-4; Malcolm Vale, 'Nobility, bureaucracy and the “state” in English Gascony, 1250-1340: a prosopographical approach’, in F. Autrand (ed.), Genèse de l'état modern: prosopographie et histoire (Paris, 1985), esp. pp. 309-10.

${ }^{170}$ Trabut-Cussac, L'administration anglaise en Gascogne, pp. 175-91, 194-211; Ruddick, ‘Gascony and the limits', in Smith (ed.), Ireland and the English world, pp. 72, 77.

${ }^{171}$ Malcolm Vale, 'Language, politics and society: the uses of the vernacular in the later Middle Ages', EHR 120: 485 (2005), 28. On the dissemination by the royal administration of Anglo-French to Gascony, Scotland, Wales and Ireland, see Serge Lusignan, La langue des rois au moyen âge: le français en France et en Angleterre (Paris: Presses universitaires de France, 2004), pp.180-5.

${ }^{172}$ See Green, ‘Lordship and principality’, esp. p. 8. More generally, see Eleanor C. Lodge, Gascony under English rule (London: Menthuen, 1926), ch. ch. 5. 
${ }^{173}$ Richard A. Newhall, 'Henry V’s policy of conciliation in Normandy’, in C. H. Taylor (ed.), Anniversary essays in medieval history by students of Charles Homer Haskins (Boston, 1929), pp. 205-29, at p. 207.

${ }^{174}$ Allmand, Lancastrian Normandy, p. 17; Curry, 'La chambre des comptes', in Contamine and Mattéoni (eds.), Les chambres des comptes, pp. 91-125.

${ }^{175}$ W. T. Waugh, ‘The administration of Normandy, 1420-1422’, in A. G. Little and F. M. Powicke (eds.), Essays in medieval history presented to Thomas Frederick Tout (Manchester: Manchester UP, 1925), 349-59, esp. 351-2.

${ }^{176}$ B. J. H. Rowe, 'The estates of Normandy under the duke of Bedford, 1422-1435', EHR 46:184 (1931), 561.

${ }^{177}$ Juliet Barker, 'The foe within: treason in Lancastrian Normandy', in Peter Coss and Christopher Tyerman (eds.), Soldiers, nobles and gentlemen: essays in honour of Maurice Keen (Woodbridge: Boydell, 2009), pp. 305-20, at p. 309.

${ }^{178}$ Shirley (ed.), Parisian journal, p. 289.

${ }^{179}$ C. T. Allmand, 'A note on denization in fifteenth century England', Medievalia et Humanistica (1966), 127-8.

${ }^{180}$ Henry Ellis (ed.), Registrum vulgariter nuncupatum “The Record of Caernarvon” (London: Record Commission, 1838), pp. 131-2.

${ }^{181}$ As Griffith observes: ‘ At the lower levels the English had long discovered that Welsh-speaking Welshmen were more satisfactorily governed by fellow Welshmen’ (Griffiths, Principality, p. xviii). See also Stansfield, 'Prosopography and the principality of Wales, 1284-1536’, 28.

${ }^{182}$ Helen Fulton, ‘Class and nation: defining the English in late-medieval Welsh poetry’, in Ruth Kennedy and Simon Meecham-Jones (eds.), Authority and subjugation in writing of medieval Wales (Basingstoke: Palgrave Macmillan, 2008), pp. 191-212.

${ }^{183}$ David Johnston, 'Iolo Goch and the English: Welsh poetry and politics in the fourteenth cnetury', Cambridge Medieval Celtic Studies 12 (1986), 73-98, at 98. 
${ }^{184}$ Glyn Roberts, 'Wales and England: antipathy and sympathy, 1282-1485’, WHR 1:4 (1963), 37596 (quotation at p. 386).

${ }^{185}$ Statutes of the realm, 4 Henry IV, c. 32. The French text appears also in Ellis (ed.), Record of Caernarvon, pp. 239-40. See R. R. Davies, The revolt of Owain Glyn D̂ैr (Oxford: Oxford UP, 1995), pp. 286-7. The statute amplifies the ordinances issued on 18 March 1401 (Foedera [O], vol. VIII, p. 184); the calendared version of this record simply states that 'certain offices in north Wales shall be held by Englishmen only’ (CPR 1399-1401, pp. 469-70).

${ }^{186}$ Frame, English lordship, ch. 3; Frame, 'Rediscovering medieval Ireland'; Crooks, 'Reconstructing the past'.

${ }^{187}$ On the application of English law to Ireland in 1210, see Gillingham, above, pp. ++; and also Paul Brand, 'Ireland and the literature of the early common law', in Brand, The making of the common law (London: Hambledon, 1992), pp. 445-63, which usefully shows how the need to issue legal guidelines (e.g. registers of writs) to the newly-acquired lordship of Ireland stimulated the process of legal definition of the common law itself.

${ }^{188}$ Frame, Political development, p. 214, brings out the contrast between Ireland and Wales. ${ }^{189}$ Robin Frame, 'Ireland after 1169: barriers to acculturation on an “English” edge’, in Keith J. Stringer and Andrew Jotischky, Norman expansion: connections, continuities and contrasts (Ashgate, 2013), esp. pp. 118-19.

${ }^{190}$ The variable texture of English power in Ireland is the theme of a seminal essay by Robin Frame: 'Power and society in the lordship of Ireland, 1272-1377', P\&P 76 (1977), 3-33 (repr. in Frame, Ireland and Britain).

${ }^{191}$ Robin Frame, 'Exporting state and nation: being English in medieval Ireland', in Scales \& Zimmer Power, pp. 143-65; Peter Crooks, 'Representation and dissent: "parliamentarianism” and the structure of politics in colonial Ireland, c.1370-1420', EHR 125:512 (2010), 1-34.

${ }^{192}$ Mark Hennessy, 'Making Ireland English in the thirteenth century: the evidence of the Irish lay subsidy of 1292', in Patrick J. Duffy and William Nolan (eds.), At the anvil: essays in honour of William J. Smyth (Dublin: Geography Publications, 2012), pp. 81-91. 
${ }^{193}$ A. J. Otway-Ruthven, A history of medieval Ireland (London: Barnes and Noble, 1968), ch. 9, 'The attempt at recovery: Lionel of Antwerp and William of Windsor'.

${ }^{194}$ For the circumstances of the appointment, see Peter Crooks, “ "Hobbes”, “dogs” and politics in the Ireland of Lionel of Antwerp, c.1361-6’, in Stephen Morillo (ed.), The Haskins Society Journal 16 (Woodbridge: Boydell, 2005), pp. 117-48, at 117-20.

${ }^{195}$ For the distinction between 'force' and 'power', see Edward Luttwak, The grand strategy of the Roman empire from the first century A.D. to the third (Baltimore: John Hopkins UP, 1976), pp. 195200.

${ }^{196}$ Rowlands, ‘Edwardian conquest’, in Herbert and Jones (eds.), Edward I and Wales, p. 48.

${ }^{197}$ Bruce Berman, Control and crisis in colonial Kenya: the dialectic of domination (London: Currey, 1990), p. 440.

${ }^{198}$ Ronald Robinson, 'Non-European foundations of European imperialism: sketch for a theory of collaboration', in Roger Owen and Bob Sutcliffe (eds.), Studies in the theory of imperialism (London: Longman, 1972), pp. 117-42, quotation at p. 124. For the Gascon parallel, see Frame, English lordship, p. 10.

${ }^{199}$ Recent debates on ‘Anglo’ settler colonialism and genocide are considered in Stephen Howe, 'British worlds, settler worlds, world systems, and killing fields’, JICH 40:4 (2012), 691-725, esp. 701-5. See also Patrick Wolfe, 'Settler colonialism and the elimination of the native', Journal of Genocide Research 8:4 (2006), 387-409; James Belich, Replenishing the earth: the settler revolution and the rise of the Anglo-World, 1783-1939 (Oxford: Oxford UP, 2009). 